\title{
Exogenous enzymes for pigs and poultry
}

\author{
M. R. Bedford and H. Schulze \\ Finnfeeds International Ltd, Marlborough, Wiltshire, UK
}

\begin{abstract}
Many feed ingredients in use in monogastric diets contain significant quantities of antinutritional factors (ANF) which limit both their feed value and their use. Almost all enzymes currently being used address such factors to varying degrees, allowing for more economic utilization of raw materials. However, animal response to xylanase, $\beta$-glucanase and even phytase utilization reported in the literature tends to vary. Factors such as enzyme source, ingredient variety and environment under which the ingredient was grown, stored and processed into animal feed, age of animal, interaction with other dietary ingredients, and health status are shown to affect significantly the response obtained. As a result, the mode of action of xylanases and $\beta$-glucanases is still debated due to too much emphasis being placed on interpretation of individual trial results without regard to the interactive factors or the literature dataset as a whole. Better understanding of such factors will improve data interpretation. While results with phytase are not subject to such extreme variation, they are nevertheless inconsistent in the degree to which inorganic phosphorus can be replaced by this enzyme. Greater understanding of the ANF and factors which interact to govern the response to added exogenous enzymes will undoubtedly improve the economic return and confidence in their use. Improved knowledge of ANF structure will result in development of enzymes directed towards far more specific targets, which enhances the likelihood of success and should reduce the overall enzyme usage.
\end{abstract}

\section{Introduction}

Evolution has undoubtedly shaped the digestive system of the jungle fowl and wild pig to deal with the dietary ingredients they encounter in an efficient manner. Systematic breeding has certainly altered not only the growth potential (Muramatsu et al. 1990; Friesen et al. 1994; Fuller et al. 1995) of these animals but has also significantly changed the structure (Hancock et al. 1995; Uni et al. 1995) and morphology (Dämmrich, 1987) of their digestive tract. The manner in which these animals are fed has not stood still either. In the wild, the diets of these animals would be made up of many different ingredients, few of which would ever reach $>30 \%$ of total intake on a lifetime basis. Such a situation has changed dramatically with modern farming practices. The range in types and relative quantities of ingredients that can be presented to the modern monogastric animal, while complex, tend to result in a diet in which 2 or 3 ingredients may constitute $>75 \%$ of intake.

Such change is driven by least cost formulation processes, and endeavours to provide maximum nutrient density for minimum cost. Inevitably, this results in diets reliant on the most 
available cereal and vegetable protein, which translates into maize, wheat or sometimes barley as the dominant cereal, and soyabean meal or rapeseed meal as the dominant protein source. Each of these ingredients contains varying quantities of several antinutritional factors (ANF), the consequence of which is minimal if fed at low concentrations but considerable if their threshold is exceeded (Sauveur, 1989; Campbell \& Bedford, 1992; Jansman et al. 1994). Modern feed formulation practices tend to create such a problem, whereby the dietary concentration of a given ANF often approaches its threshold due to the economically attractive nature of the cereal or protein meal for achieving the goal of nutrient provision. Because of natural variation in the content of ANF (Matthaus, 1997) these thresholds are sometimes unwittingly exceeded.

The activity of such ANF depends upon the antinutrient concerned and the concentration in the final ration (Huisman \& van der Poel, 1987; Sauveur, 1989; Annison, 1990; Campbell \& Bedford, 1992; Dintzis et al. 1992; Huisman, 1992; Liener, 1994; Tamminga et al. 1995). Many ANF are antinutritional because they are not degraded sufficiently or indeed at all by the conditions and digestive enzyme array in the gastrointestinal tract. In such cases, any process which will reduce ANF concentrations will enhance performance and relax some of the constraints on feed formulation. It is under such circumstances that exogenous enzymes can be of benefit. They may simply supplement those enzymes that are present in the digestive tract to a level that is effective, or provide hydrolytic capacity that is totally absent. The enzymes that will be covered by this review are those that are absent in the normal digestive processes of the pig and chicken. Addition of exogenous amylases and proteinases has been shown to be of benefit in both the pig and chicken (Ritz et al. 1995; McNab et al. 1996) and suggests that this is an area requiring more attention. This review will focus more on the enzymes currently in commercial use worldwide, which in decreasing order of commercial value are the xylanases (having by far the greatest share of current enzyme sales), phytases and $\beta$-glucanases. These enzymes are virtually absent from the intestinal tract of the animal, while their target substrates are present in the average monogastric ration in relative abundance.

The relevance and results of using these enzymes will be dealt with on a species basis wherever possible, since it is evident that differences in the digestive tract between the pig and the chicken are such that different ANF have varying importance.

\section{Differences in digestive tract structure which influence the susceptibility of pigs and poultry to various ANF}

The pig and chicken differ quite considerably in digestive physiology and in their development from ‘birth' (Manners, 1976; Widdowson, 1985; Nitsan et al. 1991; Nir et al. 1993). The elements of particular interest in this review are the retention time of feed in the gastrointestinal tract and the dry matter of the material as it passes through the small intestine. The chick certainly has a much faster rate of passage than the pig, approximately $2-4 \mathrm{~h} v .12-24 \mathrm{~h}$ (Entringer et al. 1975; Mateos et al. 1982; Johansen et al. 1993). It also tends to have far less moisture in the small intestine, 16-20\% dry matter (DM) (Bedford et al. 1991) v. 7-10\% (Bedford et al. 1992) for the chick and pig respectively. While the gastric phase of the chick's digestive system may last only $20-45 \mathrm{~min}$, it can average $4-8 \mathrm{~h}$ in the pig. Such differences confer considerably different stresses on the feed materials and possibly explain some of the notable differences in response to enzyme supplementation. Chicks certainly have much higher viscosities of intestinal digesta than pigs when fed relatively similar diets (Bedford et al. 1990, 1992), which is probably a function of the differences in DM. Solutes in the lumen of the chick 
are effectively concentrated, perhaps as much as two-fold, compared with those in the pig. The pig ultimately dilutes the feed with a greater volume of pancreatic juice and water, which markedly alters the rheological and thus the subsequent kinetic parameters of digestion. These differences will be discussed in the light of the topics reviewed herein.

\section{Xylanases and $\beta$-glucanases-Diversity in their source and characteristics}

Xylans and $\beta$-glucans exist in huge quantities in nature as principal components of plant cell wall material (Bastawde, 1992; Theander et al. 1993). They therefore provide substrates for many organisms which derive energy through metabolism of the constituent sugars (xylose, glucose and arabinose). While the underlying structure of most xylans is similar, i.e. a $\beta-1,4$ linked backbone of $D$-xylose residues, in practice the variety is enormous due to differences in backbone size and in type and degree of substitutions from the backbone, all of which depend on the source of the xylan (Bastawde, 1992; Sunna \& Antranikian, 1997). Hardwood, softwood and cereal xylans, for example, are very different in all three categories identified above. The substitution pattern, in particular, can vary significantly from source to source, the substituents most commonly being $\alpha-4-O$-methylglucuronic acid, arabinose, acetic acid, and various phenolics linked through substituent sugars. The position of the substituent on the xylan backbone (i.e. linked at $\mathrm{C} 2,3$ etc.) varies depending on the source. Differences in $\beta$-glucan structure from plant to plant are also evident (Bastawde, 1992; Heredia et al. 1995). The principal $\beta-1,4$ glucose backbone can vary in length and in degree and pattern of substitution with $\beta-1,3$ linkages (Dais \& Perlin, 1982; Edney et al. 1991). Substitution patterns in both xylans and $\beta$ glucans alter not only their physical properties, e.g. solubility, water binding capacity, viscosity, but also their susceptibility to attack by enzymes (Ogawa, 1988; Bastawde, 1992; Bhat \& Bhat, 1997; Ito, 1997; Shoemaker et al. 1983).

As a result of such heterogeneity in plant cell wall structure, a plethora of xylanolytic and glucanolytic systems has evolved, each with their own characteristics. Hydrolysis of xylan requires the presence of an enzyme system comprising a $\beta-1,4$ endoxylanase (which cleaves the internal linkages of the xylan backbone), a $\beta$-D-xylosidase (which hydrolyses short xylooligosaccharides from the nonreducing end to release xylose), and enzymes designed to release the substituents. Sunna \& Antranikian (1997) list the characteristics of endoxylanases produced from 31 fungal and 31 bacterial species (in some cases each species producing as many as 5 xylanases). The range ( $\min$ and $\max$ ) of some of the characteristics is summarized in Table 1 and shows that there is considerable variation in enzyme capabilities. This results from the wide

Table 1. Variation in catalytic and physical properties of endoxylanases from 31 species of bacteria and 31 species of fungi

\begin{tabular}{lccccc}
\hline Organism & $\begin{array}{c}\text { Optimal } \\
\text { temperature }\end{array}{ }^{\circ} \mathrm{C}$ & $\begin{array}{c}\text { Optimal } \\
\mathrm{pH}\end{array}$ & $\begin{array}{c}\text { Molecular } \\
\text { weight }\end{array}$ & $\begin{array}{c}\text { Vmax } \\
(\mathrm{U} / \mathrm{mg})\end{array}$ & $\begin{array}{c}\mathrm{Km} \\
(\mathrm{mg} / \mathrm{ml})\end{array}$ \\
\hline Fungi Min & 30 & 2.0 & 13,000 & 0.37 & 0.09 \\
Fungi Max & 80 & 7 & 95,000 & $1.4 \times 10^{4}$ & 22.3 \\
Bacteria Min & 30 & 4.5 & 13,200 & $1.7 \times 10^{-2}$ & 0.07 \\
Bacteria Max & 105 & 10 & 350,000 & $7.6 \times 10^{3}$ & 17.7 \\
\hline
\end{tabular}

Data derived from Sunna \& Antranikian (1997). 
variation not only in substrate structure, but also in the environments in which these substrates are found-arctic $v$. tropical areas of the planet and alkaline $v$. acidic soils for example.

Some endoxylanases require lengths of unsubstituted xylan in order to bind and hydrolyse the backbone, while others are not so demanding (Bastawde, 1992; Sunna \& Antranikian, 1997). As a result there are differences between enzyme sources in their dependence on the accessory or debranching enzymes (e.g. acetyl xylan esterase, arabinosidase) for depolymerization of the backbone. Regardless of catalytic properties, the goal of these enzyme systems is to provide sugars for the organisms that produce them. Such sugars may be in the form of oligomers of 3-4 sugar length or single sugars, depending on the requirements of the organism involved. While these characteristics are designed and set by the evolution of the organism, the efficiency of such enzymes in animal feed applications depends very much on a completely different set of criteria which depend on the mechanism of action of the enzyme in animal feed usage; this is discussed below.

\section{Xylanases and $\beta$-glucanases-Mechanism of action in pig and poultry feed}

Virtually all applications of xylanases and $\beta$-glucanases in animal feeds are currently targeted at the cereals wheat, rye, barley, oats and triticale. These cereals constitute a lesser component than maize in poultry and pig feeds on a global scale, but regionally they are dominant in areas of Northern Europe, Canada and Australia either throughout the year or seasonally.

It is reasonably safe to state that both xylanases and $\beta$-glucanases significantly increase the digestibility of wheat and barley based diets respectively, but the mechanism by which this is brought about has been debated over the past 10 years. Two main schools of thought exist. One is based on the fact that the cell walls of the cereal endosperm, which are composed of xylans, $\beta$-glucans and cellulose (the relative proportions depending upon the cereal), encapsulate starch and protein. Since the monogastric animal does not have the enzymic capacity to digest such structures, the contents of intact endosperm cells effectively escape digestion (Pettersson \& Åman, 1988; Pettersson et al. 1990; Cowan et al. 1993). Provision of exogenous enzymes which degrade such structures effectively removes the cell wall and thus facilitates digestion. This hypothesis remains difficult to defend on the basis of digestibility data and enzyme kinetics. The use of cell wall degrading enzymes has consistently been shown to improve fat digestibility (Campbell et al. 1983; Classen et al. 1985; Edney et al. 1989; Carre et al. 1992; Danicke et al. 1995), often to a greater extent than that of any other nutrient, and since little or no dietary fat is encountered in cereal endosperm cells, it is unlikely that cell wall dissolution per se plays a large part in describing the action of such enzymes.

It has been suggested by Chesson \& Travis (1997) that the average pore size in graminae cell walls is too small for the average xylanase or amylase, let alone a bacterium, to penetrate. Modelling of cell wall degradation by cellulolytic bacteria over a period of $24 \mathrm{~h}$ demonstrated that there was no net increase in cell pore size, simply a reduction in total insoluble biomass (Chesson \& Travis, 1997). Thus it is unlikely, given the time constraints placed on added enzymes by the digestive system of the pig and particularly the chicken, that significant cell wall dissolution will occur. Moreover, increased endosperm cell wall degradation in vitro on addition of very high rates of xylanase and cellulase (Tervila-Wilo et al. 1996) did not result in increased starch hydrolysis in the presence of amylase. This suggests that the cell wall disruption that did take place was of cells already broken open. Furthermore, in vitro simulation has shown little if any changes to the microscopic structure of wheat endosperm cell walls (Morgan et al. 1995). Nevertheless, microscopic analysis of the intestinal contents of the broiler 
has indicated increased damage to endosperm cell wall structure on addition of a Trichoderma xylanase, but interestingly this is most evident at the level of the gizzard (Bedford \& Autio, 1996). As such, this may not be due directly to the effect of the enzyme on endosperm cell walls, but perhaps on its ability to produce soluble, fermentable oligomers which enter the caeca and enhance fermentation (Choct et al. 1996). Research with rats has shown that enhanced fermentation in the colon elevated enteroglucagon concentrations, which in turn depressed gastrin concentrations markedly, thereby slowing gastric emptying but increasing motility (Gee et al. 1996). It is feasible, therefore, that xylanases indirectly enhance cell wall breakdown through stimulating gizzard/stomach function.

An alternative hypothesis relates to the fact that some of the cell wall components of these cereals dissolve in the digestive tract and interact to form high molecular weight, viscous aggregates (White et al. 1981, 1983; Fengler \& Marquardt, 1988a; Bedford et al. 1991; Bedford \& Classen, 1992a,b; Annison, 1993). They present problems to pigs, but to poultry in particular when fed in excess through increasing the viscosity of the intestinal digesta, which is known to (i) reduce the gastrointestinal passage rate (van der Klis et al. 1993; Almirall \& Esteve-Garcia, 1994; Sudendey \& Kamphues, 1995); (ii) reduce diffusion of digestive enzymes, their substrates and their products (Johnson et al. 1984; Fengler \& Marquardt, 1988b; Bedford \& Morgan, 1996; Ellis et al. 1996); (iii) promote the secretion of endogenous enzymes (Choct \& Annison, 1992; Larsen et al. 1993; Angkanaporn et al. 1994; Inborr et al. 1994); and (iv) stimulate bacterial proliferation, particularly in the small intestine (Annison \& Choct, 1991; Choct et al. 1996; Hock et al. 1997). Each of these responses will be discussed in more detail later. While the source of the viscous polymer is of interest (it is a complex of arabinoxylan in the case of wheat, triticale and rye, or $\beta$-glucan in the case of barley and oats (White et al. 1983; Ahluwalia \& Ellis, 1985; Fengler \& Marquardt, 1988a; Delcour et al. 1991; Girhammar \& Nair, 1992a; Izydorczyk \& Biliaderis, 1992a; Autio, 1997)), the end result of excess intake is poor digestive efficiency. The bulk of the research into viscosity problems has focused on barley, rye and wheat, but many of the findings are applicable across cereal species and are discussed below. The actual intestinal viscosity measured is dependent upon a number of factors, including grain species, variety and environment under which it was grown (Classen et al. 1985; Bedford, 1996b). Fig. 1 shows the determined viscosity of wheat \& barley (Waldron \& Bedford, 1997, pers. comm.) averaged over many varieties and climates but presented on a country basis over a 2 year period. The higher the extract viscosity, the more viscous the intestinal contents will become on feeding this sample, and hence the larger the response expected upon enzyme supplementation. Such data demonstrate that large and almost contrary responses due to enzyme addition would be expected in the literature as a result of cereal viscosity variation alone.

A few, relatively well targeted hydrolytic events need to take place to reduce viscosity significantly since the molecular size and concentration of a viscous polymer is exponentially related to subsequent solution viscosity (Bedford \& Classen, 1992a,b; Izydorczyk \& Biliaderis, $1992 b$ ). Such a limited number of hydrolytic events favours this mechanism over the cell wall mechanism. For viscosity reduction, these hydrolytic events need to be aimed as close to the centre of the polymer as possible (i.e. endo-acting enzymes) rather than at the exposed ends of the chain (exo-acting enzymes) if rapid molecular weight reduction is to be achieved. Evidently, the relative efficacy of enzymes from different source organisms will differ in achieving this objective.

The xylan backbone can be highly substituted with arabinose in wheat, rye and triticale (Dudkin et al. 1976; Saini \& Henry, 1989; Annison et al. 1992; Girhammar \& Nair, 1992b; Vinkx \& Delcour, 1996). Such substitution interferes with the in vitro activity of many 


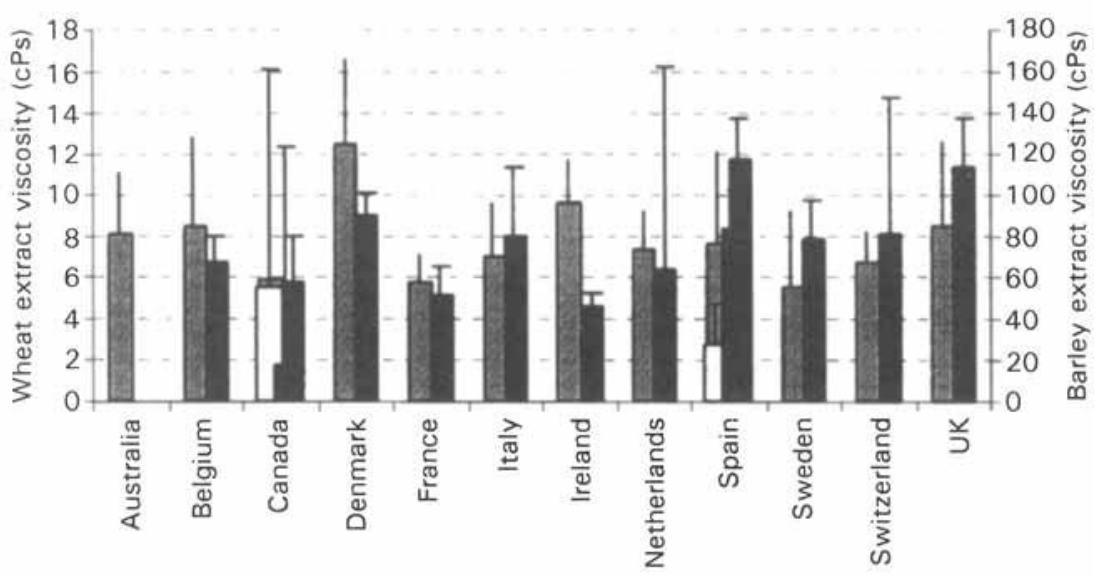

Wheat 96 Wheat $97 \quad \square$ Barley 96 Barley 97

Figure 1. Effect of cereal species, source and year of production on extract viscosity measurement (mean \pm SD; Waldron \& Bedford (1997), pers. comm.). Sample sizes per country range from 5 to 43 . Method used for extract viscosity determination is based on that of Bedford \& Classen

(1992a).

endoxylanases, some being particularly sensitive to the presence of such moieties and thus responding to the addition of accessory activities which remove or debranch the xylan backbone (Poutanen, 1988; Poutanen et al. 1991; Tenkanen et al. 1991; Sunna \& Antranikian, 1997). While in vitro reaction kinetics clearly indicate the benefit of combination of the endoand debranching enzymes, the benefit of such side activities in practice, however, does not seem to be so clear cut. Grootwassink et al. (1989) indicated that a crude preparation from Aspergillus niger which contained the xylanase and debranching activities resulted in better chick performance than the purified xylanase alone. Bedford \& Inborr (1993) and Cowan et al. (1993), however, found that the purified xylanases from Humicola insolens or Trichoderma respectively outperformed the crude preparations which contained debranching activities. It appears, therefore, that the source of the xylanase can influence its requirement for accessory activities if maximum depolymerization is to be achieved.

When considering the source organisms of the current commercial xylanases and $\beta$-glucanases (from Aspergillus, Trichoderma and Humicola), their physical and catalytic properties are markedly different (Ito et al. 1992; Wong \& Saddler, 1992; Kormelink et al. 1993; Düsterhöft et al. 1997). Even xylanases derived from the same organism differ markedly in their catalytic activities on various xylan substrates (Kluepfel et al. 1992; Table 2), preventing meaningful interpretation of results if the relative presence of each of the isozymes is not disclosed. As a result, presentation of data on the effect of a xylanase without disclosure of the source organism and relative presence of isozymes, and its activity on a defined substrate which bears resemblance to the substrate in the feed, is of limited value.

The various $\beta$-glucanases and cellulases on the market at present are subject to similar constraints. Since the effect of these enzymes on cereal arabinoxylans or $\beta$-glucans is so different, 'broad brush' conclusions on mechanisms of action of all xylanases or $\beta$-glucanases should be drawn with caution on the basis of studies in which only one source is investigated. 
Table 2. Comparison of specific activities and $\mathrm{Km}$ of xylanases $\mathrm{A}, \mathrm{B}$ and $\mathrm{C}$ from Streptomyces lividans on two different xylan substrates (Kluepfel et al. 1992)

\begin{tabular}{lccccr}
\hline \hline & \multicolumn{2}{c}{ Oat spelt xylan } & & \multicolumn{2}{c}{ Birchwood xylan } \\
\cline { 2 - 3 } \cline { 5 - 6 } & $\mathrm{Km}$ & & & $\mathrm{Km}$ & Vmax \\
\hline Xylanase A & 2.6 & 5570 & & 1.1 & 616 \\
Xylanase B & 3.7 & 1960 & & 1.8 & 921 \\
Xylanase C & 4.2 & 650 & & 4.1 & 3022 \\
\hline \hline
\end{tabular}

Evidence to counter the viscosity mechanism

There still remain several reports suggesting that intestinal viscosity is not a factor in determining the response to exogenous enzymes, particularly if it is less than $10 \mathrm{cP}$. In many cases, however, the hypothesis has not been tested correctly, either through use of enzymes which do more than simply reduce viscosity or through reformulation which alters far more than diet viscosity (see Bedford, 1996a; Bedford \& Morgan, 1996).

A further observation of note is that a measurement of intestinal viscosity is a point in time determination. This value is then regressed against a performance characteristic, and conclusions drawn on the basis of the presence or absence of a regression. Intestinal viscosity, apparent metabolizable energy (AME) and feed conversion ratio (FCR) are undoubtedly subject to diurnal variations. It is evident that FCR and AME values will more accurately reflect the true mean since they are average values taken over a period of time. Intestinal viscosity, on the other hand, is measured at point of slaughter. It is not only subject to diurnal rhythms, but also to individual bird water intake patterns and pancreatic serous secretion output. Both of these activities will be influenced by length of fasting prior to slaughter and both will significantly dilute gut contents and hence lower measured viscosity. It is not uncommon to see coefficients of variation as high as $75 \%$ in viscosity data sets. While 4 or 5 replicates is often adequate for digestible energy (DE), AME and FCR determination, our experience suggests that as many as 12-16 replicates are required for a reasonable estimate of intestinal viscosity for any particular diet. Furthermore, much of the dissenting data has been analysed by inappropriate statistical methods. Often point to point comparisons are made where regression analysis may have yielded a different interpretation. Moreover, the lack of a relationship between intestinal viscosity and performance on the basis of such analysis is incorrectly interpreted as support for the alternative cell wall hypothesis. There is only one published paper where the relationship has been tested correctly, and in this study there was a very strong correlation between FCR and intestinal viscosity (at values ranging from 3 to $12 \mathrm{cP}$; Bedford, 1995, Fig. 2). In the aforementioned study, all diets were identical apart from the content of a viscosity reducing enzyme.

Restrictions on nutrient extraction due to reduced rates of diffusion/convection

Genetic selection has resulted in animals with very much accelerated rates of metabolism and increased intestinal efficiency (Bulfield et al. 1988; Mitchell \& Smith, 1991; Stern et al. 1995; Jackson \& Diamond, 1996). Demands on the ability of the gut to provide the nutrients required 


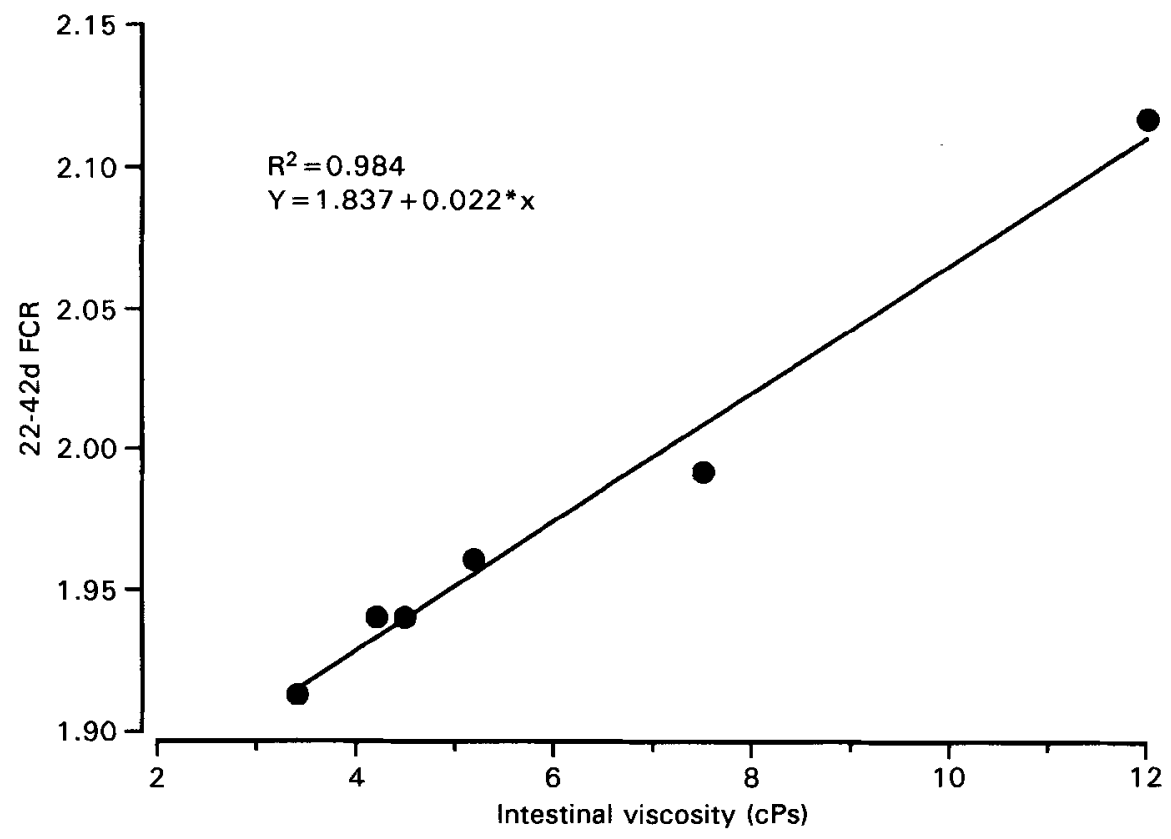

Figure 2. Effect of intestinal viscosity measure at $21 \mathrm{~d}$ old on subsequent performance of broiler chicks to $42 \mathrm{~d}$ old (Bedford, 1995). Diets (wheat based) were identical apart from inclusion of xylanase at $0,600,1200,1800,2400,3000$ $\mathrm{U} / \mathrm{kg}$.

for growth increase year by year such that minor perturbations in nutrient supply will result in more and more dramatic effects on growth rates and efficiency.

The broiler, turkey and piglet have been reported to be slow to develop to the full their digestive enzyme capacity and intestines to meet the demands of growth as they age (McConlogue et al. 1984; Lindemann et al. 1986; Owsley et al. 1986; Cera et al. 1988; Krogdahl \& Sell, 1989; Sell et al. 1989; Nitsan et al. 1991; Noy \& Sklan, 1994; Uni et al. 1995). Neonates have to deal very rapidly with the transition from zero zymogen release from the pancreas prior to 'birth', to reacting to the presence of feed in the gut and release of the relevant enzymes. This process may not be particularly well coordinated in younger animals (Uchiyama \& Watanabe, 1990) and may quickly deplete the pancreas of reserves (Nitsan et al. 1991). Even in older animals, pancreatic adaptation to changes in dietary input takes a minimum of $24 \mathrm{~h}$ and changes are still measurable 5-7d later (Pinchasov et al. 1990; Le HuerouLuron et al. 1993). Coupled with the observation that feed is resident in the small intestine for only $4 \mathrm{~h}$ and often less than 2, depending on diet (Mateos et al. 1982; van der Klis et al. 1990; van der Klis \& Van Voorst, 1993), there may be several circumstances where there is insufficient time for complete digestion of the feed. Such a statement seems to run counter to the commonly held tenet that there is some 100 times more enzyme released into the lumen (Makkink \& Verstegen, 1990) of the intestine than would be required by the quantity of substrate. However, such statements are based on in vitro determinations of enzyme activity which do not take into account poor accessibility of substrate (e.g. encapsulated by plant cell walls), reduced enzyme mobility or varying feed transit times. The fact that there is significant adaptation of pancreatic enzyme output in response to dietary change (Mourot \& Corring, 1979; Makkink \& Verstegen, 1990; Pinchasov et al. 1990; Uchiyama \& Watanabe, 1990; 
Lhoste et al. 1993) and that blood borne nutrients are lower in broilers compared with layers (Mahagna \& Nir, 1996), suggesting that demand is outstripping supply, clearly indicates that digestion in rapidly growing animals is on the limit of the adaptive capacity of the bird. Therefore, any event that delays or impedes the rate of digestion will have a significant effect on the overall digestibility of a ration. An increase in intestinal viscosity is one such event, and its ramifications are discussed below.

Some authors have indicated that increased viscosity significantly reduces the rates of diffusion of solutes (Fengler \& Marquardt, 1988b; Bedford, 1996a) and others that viscosity severely restricts convectional movement of material in the lumen (Edwards et al. 1988). Restricted diffusion slows the rate of digestion and thus rate and efficiency of growth suffers (White et al. 1983; Bedford et al. 1992; Bedford \& Classen, 1992a; Almirall et al. 1995). The animal has some capacity to compensate as luminal viscosity increases through increased pancreatic enzyme output and growth in both length and weight of the small intestine and height of the villi (Angkanaporn et al. 1994; Viveros et al. 1994; Smits et al. 1997), but ultimately a point is reached beyond which the bird has no further capacity to respond to the challenge and performance suffers (Angkanaporn et al. 1994). In any case, in responding to such a challenge the animal expends more energy in extracting dietary nutrients and feed efficiency will suffer.

Restricted convectional movement will most dramatically impair fat digestion, particularly that of saturated fats, owing to the reliance of this process on thorough emulsification. Fat emulsification is severely reduced with only minor $(1-5 \mathrm{cP})$ increases in viscosity of the aqueous phase (Pasquier et al. 1996, Fig. 3), the result being the appearance of larger and larger droplets of fat in the digesta as its viscosity increases (Kanauchi et al. 1995), concomitant with

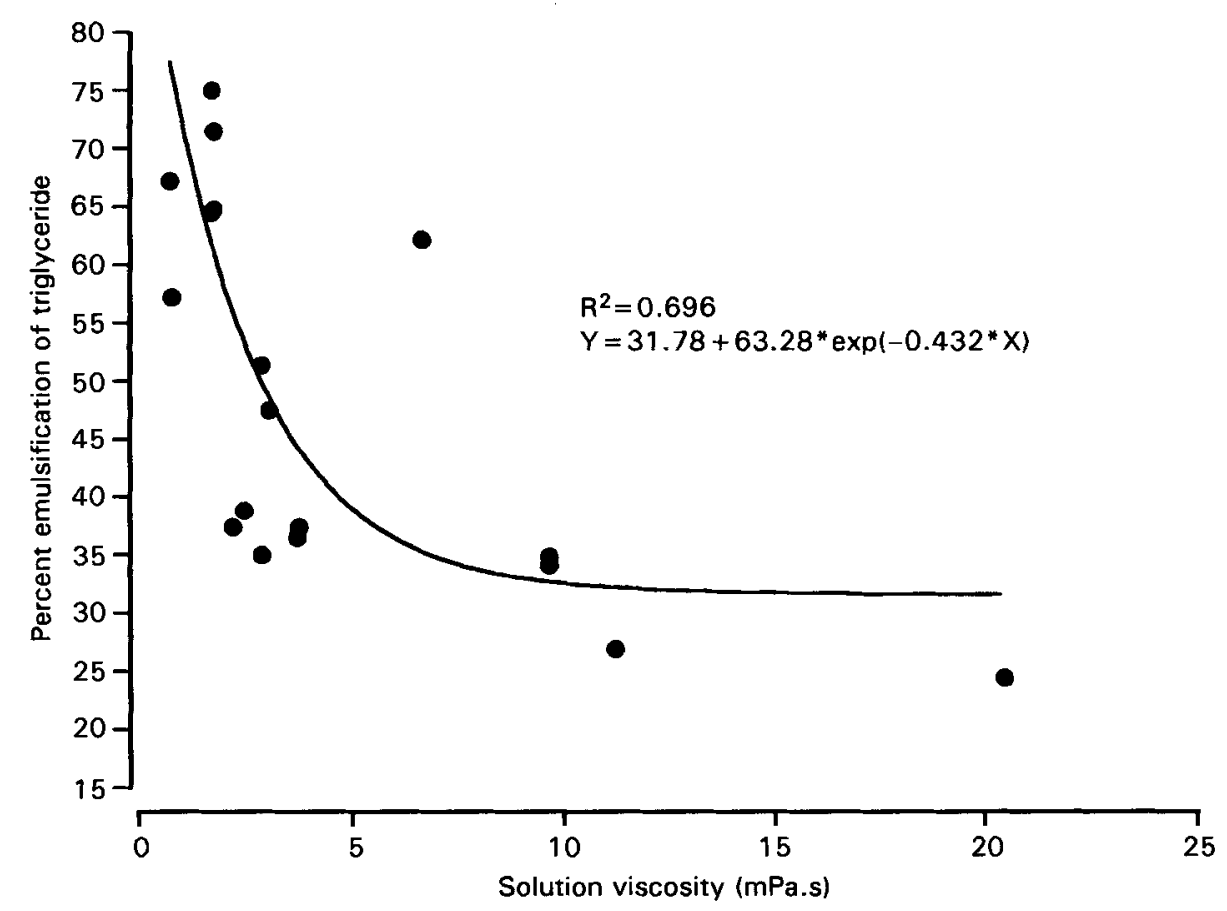

Figure 3. Effect of solution viscosity on the percent of triglyceride emulsitied after a standard agitation and rest period. (Pasquier et al. 1996). 
poorer fat digestibility (Classen et al. 1985; Wang et al. 1992; Viveros et al. 1994; Danicke et al. 1995). One further consequence of reduced convectional motility is a reduction in feed passage rate due to reduced ability of the gut to move material through its length (van der Klis \& van Voorst, 1993; Almirall \& Esteve-Garcia, 1994). Caution is required in interpreting the literature, however, since it is likely that the influence of increasing intestinal viscosity on transit time is not consistently unidirectional. Re-analysis of the data presented by Bedford \& Classen $(1992 a, b)$ indicates that feed intake of broilers is actually stimulated as intestinal viscosity increased towards $20 \mathrm{cP}$, but is severely depressed as this limit is exceeded. This is perhaps due to the ability of the bird to perceive what is effectively a nutrient dilution and respond by increasing intestinal throughput by increasing musculature of the gut. The adaptational abilities of the bird are evidently not limitless, and beyond a certain point, reduced feed passage rate results; this is cited as one of the benefits of added fat. Increasing contact time between feed and digestive enzymes in the digestive tract results in improved diet digestibility (Mateos et al. 1982). In the case of viscosity induced reduced feed transit rate, however, digestion is not enhanced and reduced feed passage rate is therefore detrimental to bird performance, for reasons discussed below.

Data for pigs are limited. Accurate intestinal viscosity determinations are more difficult to determine in the pig owing to limitations in animal numbers and because the viscosity of most samples is so low that they often approach the detection limits of the equipment used. Nevertheless, the fact that viscosity reduction has been associated with improved nutrient digestion (in fact, fat digestibility was greatly improved) in pigs (Dusel et al. 1997) suggests that this mechanism may still be important. While nutrient diffusion and fat emulsification may well be affected directly by increased intestinal viscosity (Dusel et al. 1997), Ellis et al. (1996) suggest that increasing gastric viscosity also increases the size of particles leaving the stomach owing to failure of the sieving mechanism. Large particles, instead of falling to the bottom of the stomach, are suspended in the viscous stomach contents and are therefore more likely to exit with each opening of the pyloric sphincter. This will impair digestion and seems to be specific to the pig. Viscosity also disturbs peristalsis, which alters gastric inhibitory polypeptide (GIP) output which in turn disturbs pancreatic secretions (Ellis et al. 1996). As a result of reduced peristalsis, digesta flow is more laminar than disturbed, and this further reduces the efficiency of digestion. Viscous nonstarch polysaccharides (NSP) may also physically coat starch granules, further reducing the rate of digestion (Ellis et al. 1996). While NSP digestibility has been shown to increase in the presence of cell wall degrading enzymes, this does not necessarily mean that cell walls are physically disrupted; rather, a layer may be peeled away. Microscopic analysis of digesta does suggest that cell walls are thinned in the presence of a xylanase in wheat fed pigs. Pigs and chickens may well diverge in this respect, therefore, since the incubation time for enzyme and substrate in the gastrointestinal tract of pigs may be sufficient to allow for some cell wall dissolution. However, the contribution that cell wall degradation makes to the response to enzyme supplementation in pigs is difficult to establish with the current dataset.

\section{Interaction with the intestinal microflora}

Reduced feed passage rate increases the time available for digesta associated bacteria to multiply prior to evacuation through the rectum, and coupled with reduced rates of digestion by the host there will of course be more substrate available in the distal parts of the small intestine for microbial fermentation (Bedford, 1996a). Evidence for the presence of such substrate in the 
terminal ileum has been implicated by the results of many digestibility studies investigating viscosity reducing enzymes (Lindemann et al. 1986; Pettersson et al. 1991; Bedford et al. 1992; Annison, 1992; Almirall et al. 1995; Jondreville et al. 1995; Scott \& Boldaji, 1997). While bacterial fermentation can provide energy to the host in the form of volatile fatty acids (Annison et al. 1968; Argenzio, 1982; Kirchgessner \& Müller, 1991), it is certainly not the most efficient method for extracting energy from starch or other metabolizable sugars. At best, the microflora can be seen as competing for those nutrients that the host animal can utilize. In many cases the increase in microbial activity in the small intestine associated with poorly digested diets can be substantial (Choct et al. 1996; Jansman et al. 1996). The addition of a Trichoderma longibrachiatum xylanase to a wheat based broiler diet not only reduced total ileal bacterial numbers by $60 \%$ but significantly reduced the proportion of bacteria with low content of guanidine:cytosine in the total DNA pool (method of Holben \& Harris, 1995), suggesting a shift away from enterococci and clostridia towards more lactobacilli and bifidobacter (Apajalahti \& M.R. Bedford, unpublished data). Furthermore, microscopic evaluation and computer aided analysis revealed that in the untreated wheat based diet the surface area presented by enteric bacteria constituted $25 \%$ of the entire small intestinal surface area, highlighting the demand they must place on the digestive system (Apajalahti, pers. comm.). Changes in microflora population size and species distribution as a result of diet change may dramatically alter not only competition for nutrients, but also the status of the immune system. Stimulation of the immune system is implicated in less efficient assimilation of nutrients (Cook, 1996), which undoubtedly reduces the energetic efficiency of lean tissue deposition.

Some confusion in the literature would therefore seem unavoidable when it is recognized that the interaction of the effect of the enzyme with the microflora in the gut plays such a large role in the scale of the response. Not only will the initial microbial challenge (which is determined by the environment, stocking density etc.) play a vital role in determining response, but also those factors such as antibiotics and coccidiostats which influence the microfloral population in their own right (Bedford, 1996c; Rada \& Marounek, 1996; Vukic Vranjes \& Wenk, 1996). In some cases they work together and synergize (Allen et al. 1996) while in others they do not (Miles et al. 1996). Even micronutrients such as zinc and copper significantly alter the microfloral fermentation profiles (Yenigun et al. 1996) and so can be expected to interact with feed enzymes. We are only now beginning to recognize the complex interactions involved in the response to added feed enzymes, and hence need to exercise caution in making judgements based on isolated trials. As a result, conclusions should only be drawn when a representative number of trials has been conducted which simulate the range of conditions likely to be encountered in the environment of interest.

\section{Phytase}

Phytase is probably the enzyme most readily recognized by monogastric nutritionists, but surprisingly it constitutes less than $20 \%$ of the total commercial enzyme usage to date.

Currently this enzyme is commercially produced by a limited number of organisms, Aspergillus sp. being the dominant source, while it is produced by many species of bacteria, yeast and fungi, as well as many plants in nature. Gene technology has even advanced to the stage where fungal phytases are now being expressed in canola ('double zero rapeseed'; Pen $e t$ al. 1993) and seeds from tobacco and tomato (Beudecker \& Pen, 1995). Such sources will ultimately become the cheapest and therefore commonest method of manufacture. Phytases suffer from the same variation from source to source (Segueilha et al. 1992; Shimizu, 1992; 
Źyła, 1992) as has been described for xylanases and $\beta$-glucanases. Consequently, as phytases from different organisms become available on the market, conflicting data and mechanisms will undoubtedly appear.

\section{Phytase as an efficacious additive to monogastric diets}

Phytic acid, the substrate for this enzyme, is a storage form of phosphorus in most plants, and in particular the cereals and oilseed legumes utilized in monogastric nutrition. The phytic acid content of a range of ingredients is shown in Table 3 . It is commonly thought that phytic acid is not digested or absorbed by monogastric animals and hence exogenous phytase is needed to make the phosphorus in this compound available. Addition of phytase to broiler and pig rations has long been known to improve phosphorus digestibility (Sauveur, 1989; Näsi, 1990; Simons et al. 1990). Additional benefits have been observed since phytate chelates many minerals and perhaps reduces protein digestibility through interference with pepsin and trypsin activity (Frolich, 1990; Torre et al. 1991; Caldwell, 1992; Źyła et al. 1995; Liebert et al. 1996). Thus there are many advantages to be gained through use of this enzyme, since phytate hydrolysis has been shown to bring about improvements in digestibility of these seemingly unrelated nutrients (Kornegay et al. 1996; Yi et al. 1996a,b). While it appears that this is a relatively simple issue of phytase degrading phytate, recent literature points to more complex interactions. On closer examination, it appears that there is variation in the absolute and relative response to phytase in the literature, reasons for which are only now becoming apparent.

\section{Phytate hydrolysis-Reasons for variation in monogastric animals}

One of the reasons for variation in response may be that the above assumptions are not correct. For example, there is evidence that soluble phytate is in fact absorbed and distributed to various tissues in the rat as inositol and variously degraded compounds, intimating the presence of an endogenous phytase (Sakamoto et al. 1993). Absorption of soluble phytate also suggests that its antinutritive capacity may be limited, since on absorption it is unavailable to chelate metal ions or inhibit pepsin or trypsin activity. The presence of an endogenous phytase has been reported in the rat (Bhandari, 1980) and bird (Wise, 1983), and more recently it has been characterized from the intestinal mucosa of the chick (Maenz et al. 1997). This endogenous enzyme is more prevalent in the laying hen than the broiler chick (60\% more activity) which is consistent with

Table 3. Phytate content (\%) of a range of feed ingredients

\begin{tabular}{lccccc}
\hline \hline Ingredient & $\begin{array}{c}\text { Matthaus } \\
(1997)\end{array}$ & $\begin{array}{c}\text { McKnight } \\
(1997)\end{array}$ & $\begin{array}{c}\text { Lantzsch et al. } \\
(1992)\end{array}$ & $\begin{array}{c}\text { NRC, } \\
(1994)^{1}\end{array}$ & Mean \pm SD \\
\hline Maize & 0.265 & 0.196 & & 0.20 & $0.220 \pm 0.038$ \\
Wheat & 0.235 & 0.255 & & 0.24 & $0.243 \pm 0.010$ \\
Barley & 0.223 & 0.230 & & 0.19 & $0.214 \pm 0.021$ \\
Soyabeans & & & $1.20 \pm 0.03$ & & $1.20 \pm 0.030$ \\
Rapeseed & & 0.372 & $1.35 \pm 0.10$ & & $1.350 \pm 0.101$ \\
Soyabean meal 48\% & & 0.870 & & 0.40 & $0.386 \pm 0.020$ \\
Rapeseed meal & & & 0.870 & 0.87 \\
\hline \hline
\end{tabular}

${ }^{1}$ NRC (1994) Calculated as difference between total and available phosphorus 
more efficient phytate utilization by the hen (Maenz et al. 1997). Such an enzyme, however, is claimed to be present in negligible concentrations in the intestinal mucosa of pigs (Pointillart, 1991), so there may be significant differences between species in their response to exogenous phytase.

The ability of the monogastric animal to utilize a significant proportion of phytate phosphorus in the absence of any exogenous phytase is made evident by Edwards' group. Phytate was evidently being digested in the young chick, according to balance studies, and in fact this could be significantly enhanced through addition of 1,25-dihydroxyvitamin D (Edwards, 1993; Sooncharernying \& Edwards, 1993). This vitamin has been shown to increase the activity of mucosal phytases (Pointillart et al. 1985) which may be one route by which the result was achieved. In addition, vitamin D status has a significant effect on calcium absorption. Several studies have shown that there is a considerable increase in phytate phosphorus digestibility through lowered calcium concentration in the ration (Fisher, 1992; Schoner et al. 1993). As a result, better calcium absorption through improved vitamin $\mathrm{D}$ status of the bird will lower its concentration in the digesta and may therefore significantly enhance utilization of phytate phosphorus. Most trials investigating the effects of phytase on phosphorus digestibility demonstrate less benefit in calcium-rich rations. Low dietary calcium is therefore employed which emphasizes the need for proper negative controls to ensure that enhanced phosphorus digestion is truly a result of phytase addition and not partly explained by use of a low calcium diet.

\section{Variation in response-Animal factors}

Phytase addition to monogastric diets has consistently been shown to allow for reduction in inorganic phosphorus $(\mathrm{Pi})$ supplements. However, the number of units of phytase required to replace $1 \mathrm{~g}$ Pi varies considerably (Table 4), depending on age or physiological status of the animal (Schoner et al. 1993; Kornegay et al. 1996; Yi et al. 1996a,b; Kornegay et al. 1997). Such replacement rates tend not to be linear, with exponentially increasing concentrations of phytase required to continue a linear increase in phosphorus release. Older birds seem to require less phytase to replace $1 \mathrm{~g}$ Pi compared with younger birds (Kornegay et al. 1997),

Table 4. Replacement rate of inorganic phosphorus by phytase as extracted from the literature

\begin{tabular}{lccc}
\hline \hline Authors & Species & Age & $\begin{array}{c}\text { U phytase to replace } \\
1 \mathrm{~g} \text { phosphate }\end{array}$ \\
\hline Kornegay et al. (1997) & Broilers & $21-49 \mathrm{~d}$ & $<400$ \\
Schoner et al. (1993) & Broilers & $<14 \mathrm{~d}$ & 570 \\
& & $<40 \mathrm{~d}$ & 850 \\
Kornegay et al. (1996) & Broilers & $0-21 \mathrm{~d}$ & 939 \\
Kemme et al. (1997) & Pigs & Piglets & 757 \\
& & Grower/finisher & 602 \\
& & Mid pregnancy & 1562 \\
Van der Klis et al. (1997) & & Late pregnancy & 676 \\
& Laying hens & Lactation & 485 \\
& & 20-24 weeks & 192 \\
& & 36 weeks & 312 \\
\hline \hline
\end{tabular}


while the efficacy of phytase is greater in lactating sows and growing finisher pigs than in piglets or mid-pregnancy sows (Kemme et al. 1997). These differences are clearly large, and thus must be taken into consideration when formulating rations. Furthermore, improvements in digestibility of crude protein and organic matter as a result of phytase addition has also been shown to increase with increasing sow parity (Kemme et al. 1997), possibly owing to interactions of feed intake and feed passage rate-i.e. incubation time.

\section{Other factors}

The replacement of Pi by phytase is very much dependent not only upon the calcium content (Schoner et al. 1993; Sebastian et al. 1996; Qian et al. 1997) but also that of cholecalciferol (Qian et al. 1997) as described above. Presence of tallow in the ration reduced phytate digestibility in broilers quite substantially (Matyka et al. 1990). These authors postulated that the reason for such an effect was through reduced populations of phytase secreting microbes in the presence of tallow.

Endogenous cereal phytase, the content of which varies according to variety and climatic conditions of cereal growth (Barrier-Guillot et al. 1996a,b) has been shown to influence the digestibility of the resident phytate in wheat (Barrier-Guillot et al. 1996a,b). The concentration of the substrate, phytic acid, also depends on variety and climate (Dintzis et al. 1992); thus variations in the performance of added exogenous phytase may, in part, be due to a varying contribution of phytic acid and phytase from the source grains.

Steam pelleting of the ration has been shown to reduce significantly the activity of endogenous phytase in wheat based pig diets, with the result that phosphorus and calcium digestibility can be decreased by as much as $10 \%$ (Jongbloed \& Kemme, 1990). Thus processing conditions can markedly alter the background endogenous phytase activity into which the exogenous phytase is introduced.

Most of the phytic acid present in cereals appears to be in the form of sodium and magnesium salts, concentrated mainly in the aleurone layer. This layer is particularly resistant to digestion and often appears intact at the terminal ileum of chickens (Bedford, 1996c; Bedford \& Autio 1996) and pigs (H. Schulze, pers. comm.). If the aleurone cell walls are not ruptured in the process of grinding or pelleting, then it is unlikely that their content of phytate will be readily accessible to phytase activity since this enzyme is far larger ( $\sim 80 \mathrm{k} \mathrm{Da}$-Dungelhoef $e t$ al. 1994; Yoon et al. 1996) than the expected pore sizes present in the plant cell wall. Thus the only route for degradation of phytate from such plant tissues is for the phytate itself to dissolve and diffuse out of the aleurone cells. This may actually be the case, since work by Parkkonen et al. (1997) clearly shows considerable removal of phytin crystals following an in vitro digestion simulation procedure. However, as the authors admit, the assay may considerably overestimate digestion owing to the minute particle size employed in the procedure and the much greater moisture contents compared with actual digesta in the pig or chick. If phytate has to diffuse out of the aleurone layer of the cereal in order to be accessible to the phytase, then greater phytate digestibilities would be expected in the pig than the chicken given the greater solubility of phytate in acid, and the longer retention time of feed in the stomach of the pig. This is in fact evident from the work of Barrier-Guillot et al. $(1996 a, b)$ who demonstrated that pigs retained more of the phosphorus from 4 samples of wheat than broilers.

There is clearly not so much confusion in the literature as regards the mode of action of phytase, but the rate at which $1 \mathrm{~g}$ Pi can be replaced by a fixed number of phytase units is clearly not a constant. Phytase will undoubtedly become a more common ingredient in poultry 
and pig diets as environmental pressures mount and understanding of its use increases, but since the consequence of inaccurate titration is quite dramatic, feed compounders will undoubtedly play safe and be cautious in exploiting its full potential until all interacting factors can be quantified.

\section{The future ?}

More than $80 \%$ of manufactured poultry feed and $95 \%$ of pig feed on a global basis does not contain an added enzyme (Finnfeeds International, unpublished). The reason for this is that it is either based on corn, sorghum, rice or another nonviscous starch source or, in the case of phytase, it is not an economical replacement of Pi. The advent of enzymes directed at the nonviscous grains (Wyatt et al. 1997a,b) opens up a new potential for enhanced nutrient digestibility in diets which are commonly thought to be more completely digested. However, the energy content of maize can vary (Leeson et al. 1993) and depends on climate and variety, and digestibility data suggest that $11-18 \%$ of starch may remain undigested at the terminal ileum in birds ranging from 4 to $21 \mathrm{~d}$ of age (Noy \& Sklan, 1994). Microscopic analysis of the intestinal contents of maize fed chicks has also indicated that large particles of undigested endosperm, containing fully intact cells, reach the terminal ileum (M. R. Bedford, unpublished). This demonstrates that nutrients are escaping digestion, even in maize based diets, and use of the correct enzyme complex can lead to improvements in nutrient assimilation and feed conversion efficiency (Wyatt et al. 1997a,b). The current uses of enzymes in pig and poultry diets are listed in Table 5. As can be seen, enzymes designed for maize based diets are more complex in their formulation compared with the relatively simple combinations of xylanases and $\beta$-glucanases encountered in wheat and barley based diets respectively. This is a result of there being no one overwhelming and consistently apparent ANF responsible for retarding the rate of digestion in such diets (as is the case with the $\beta$-glucans or arabinoxylans in a barley or wheat based diet respectively), but rather a complex of associated factors. It is apparent, for example, from work by Bedford et al. (1995, unpublished) that there may well be synergy between proteinases and amylases in maize based diets (due to the proteinase presumably exposing the starch granules to amylase attack) which need exploration in a factorial design in order to generate an optimum product. Synergic interaction between enzymes is certainly not new, as it has been demonstrated between phytases and acid phosphatases, proteinases and

Table 5. Content of ANF of cereals and likely enzymic solution

\begin{tabular}{|c|c|c|c|}
\hline Target & Likely ANF & Effect of ANF & Suitable enzyme \\
\hline Barley, oats & $\beta$-glucans & $\begin{array}{l}\text { Viscous digesta-wet litter, } \\
\text { poor nutrient digestibility } \\
\text { and bird performance }\end{array}$ & Endo- $\beta$-glucanase \\
\hline Wheat, rye, triticale & Arabinoxylans & $\begin{array}{l}\text { Viscous digesta-wet litter, } \\
\text { poor nutrient digestibility } \\
\text { and bird performance }\end{array}$ & Endoxylanase \\
\hline $\begin{array}{l}\text { All } \\
\text { All cereals }\end{array}$ & $\begin{array}{l}\text { Phytate } \\
\text { Resistant starch }\end{array}$ & $\begin{array}{l}\text { Poor mineral and } P \text { digestibility } \\
\text { Poor energy digestibility } \\
\text { and increased microfloral } \\
\text { populations }\end{array}$ & $\begin{array}{l}\text { Phytase } \\
\text { Amylase, xylanase, } \\
\text { proteinase }\end{array}$ \\
\hline
\end{tabular}


xylanases to name a few (Źyła, 1993; Ullah \& Phillippy, 1994; Guenter et al. 1995; Źyła et al. 1995; McNab et al. 1996). Such interactions can be due to a concerted attack on similar targets (e.g. proteinase and amylase as above), one enzyme removing and hence reducing end product inhibition of another (e.g. $\beta$-glucanase and cellobiase) or independent attacks on separate substrates of equal growth inhibiting importance (e.g. proteinase attack on trypsin inhibitor coupled with xylanase attack on arabinoxylan from wheat resulting in removal of both ANF). Clearly the challenge is to identify the ANF correctly in the form that they present themselves in the intestinal tract in order to design enzymes better suited to their destruction. This process has only just started.

The fact that enzymes are also currently thought to have considerable activity during the feed conditioning process (Bedford et al. 1997) indicates that there is considerable potential for tuning both processing conditions and enzyme properties (heat stability, $V_{\max }$ and $K_{m}$ ) to maximize subsequent nutrient utilization. The conditions in the feed conditioning kettle are far more easily regulated than those in the intestinal tract of the bird, so that variation in bird performance can be minimized if the activity of the enzyme takes place during the mechanical process of feed manufacture rather than the physiological process of digestion. This evidence also suggests that feed assays for the measurement of residual activity may prove useless for predicting subsequent bird performance. Thus alternatives or modifications to simple residual xylanase or $\beta$-glucanase assays in complete feeds must be developed if they are to be of use to the feed manufacturer.

Enzyme assisted processing of some of the oilseed meals prior to utilization in monogastric feeds is also likely to take place in the near future. Many of the soyabean meal and canola meal targeted enzymes work well when incubated together with the meal, but fail to give as good performance enhancements when the target substrate is diluted in a compound feed (Huo et al. 1993; Bedford \& Morgan, 1995).

It must be recognized that the current xylanases commercially in use arise from at most 4 genera of fungi or yeast, whereas the xylanases from 19 fungal and 8 bacterial genera have been characterized in detail (Sunna \& Antranikian, 1997). The reason for this is that the current commercial enzymes are produced by organisms which have been cultured on a large scale for other purposes, but undoubtedly some of the more novel enzymes will be better suited to the requirements of the animal feed industry. Once the key requirement for each enzyme is identified, the best candidate can be cloned into a producing organism and large advances can be expected in a relatively short period of time.

A final consideration is 'targeted' enzymes or enzymes which attach only to the substrate for which they are designed (Marquardt et al. 1996). For example, lectins and trypsin inhibitors in soyabean meal can be degraded by specific proteinases (Hessing et al. 1995), but the addition of these to soyabean meal or even compound feed presents the enzyme with many other substrates. If the enzyme were attached to a monoclonal antibody which recognized and directed the enzyme to its substrate, then the consequences would be twofold. Firstly, there would be far more efficient use of the catalytic activity of the enzyme, resulting in much lower inclusion rates than would otherwise be required to ensure adequate destruction of the target substrate. Secondly, usage of an enzyme which targets only its intended substrate prevents it from interacting in any other way with the feed, positively (by protein degradation in proteinase deficient animals) or even negatively (in the case of production of bitter peptides, for example). Thus the results from the use of such a product would be far more predictable.

Transgenic animals perhaps present the ultimate evolution of feed enzymes. Incorporation of the relevant exogenous gene into the animal itself, while appearing obvious, has several obstacles in its path. 
- The diet the animal is fed changes with the relative prices of raw materials. A bird optimized to feed on barley based diets through insertion of a functioning $\beta$-glucanase into its pancreatic array of enzymes would have no advantage when economics drive the feed producer to switch from barley to wheat.

- The current enzymes being utilized in animal feeds are but the first wave of discovery. There are undoubtedly far better, more efficient and much cheaper alternatives to all the products on the market today. Any transgenic animal is at least 5 years from reaching the market even if it were available today, owing to the laborious process of multiplying the stock in sufficient numbers to satisfy the demand for broiler production, for example. While these animals were being multiplied, newer, more efficient enzymes would be in process of production through a much more rapid fermentation process, and would render the transgenic animals relatively inefficient.

- With greater understanding of the complexity of the interactions between feed raw materials, feed enzymes may themselves become complex mixtures. As a result the number of genes that may need expression within the pancreas could be quite large and impose a metabolic cost on the animal if the substrates were not present in the ration for the reason listed above.

While transgenic animals will undoubtedly surface in the near future, the introduction of exogenous enzymes into the genome of pigs and chickens will probably make a later rather than earlier appearance.

\section{Conclusions}

Nutrient supply has been improved through better estimates of nutrient requirements and availability of synthetic amino acids and vitamins to meet them. Feed processing has advanced and more energy intensive processing conditions disrupt cell walls and gelatinize starch (Peisker, 1992), enabling the animal to utilize a higher percentage of the nutrients in the ration. Some negative effects such as increased feed viscosity (Nissinen, 1994) and possible vitamin destruction need to be addressed (Peisker, 1992; Pickford, 1992; Coelho, 1994) to maximize the potential of such processes. However, such advances may not keep pace with the genetic potential of the animals concerned with the result that the cost of providing them with nutrients for maximum growth and efficiency of growth will become prohibitive. Thus a compromise will be reached whereby acceptable growth rates are achieved at a far lesser cost. Enzyme application will aid in bridging the gap between potential and actual performance of the animal, whether the target is most rapid or most cost effective or resource efficient growth. Regardless of the goal of animal production, enzymes will aid performance through removal of ANF, breaking open cell walls, releasing phytate phosphorus, improving protein digestibility and provision of substrates for beneficial microflora. It is likely that most global monogastric feed will be enzyme treated by the year 2000 , with some enzymes being introduced at the point of feed manufacture, and some being used in the process of production of some raw materials, e.g. oilseed meals.

\section{References}

Ahluwalia, B. \& Ellis, E. E. (1985). Studies of $\beta$-glucan in barley, malt and endosperm cell walls. In New Approaches to Research on Cereal Carbohydrates (Progress in Biotechnology 1), pp. 285-290 [R.D.Hill, editor]. Amsterdam: Elsevier. 
Allen, C. M., Bedford, M. R. \& McCracken, K. J. (1996). Interactions between rate of wheat inclusion, variety, antibiotic and enzyme addition in the responses of broilers to heat-treated, pelleted diets. British Poultry Science 37 (Suppl.), S45-S46.

Almirall, M. \& Esteve-Garcia, E. (1994). Rate of passage of barley diets with chromium oxide: influence of age and poultry strain and effect of $\beta$-glucanase supplementation. Poultry Science 73, 1433-1440.

Almirall, M., Francesch, M., Perez-Vendrell, A. M., Brufau, J. \& Esteve-Garcia, E. (1995). The differences in intestinal viscosity produced by barley and $\beta$-glucanase alter digesta enzyme activities and ileal nutrient digestibilities more in broiler chicks than in cocks. Journal of Nutrition 125, 947-955.

Angkanaporn, K., Choct, M., Bryden, W. L., Annison, E. F. \& Annison, G. (1994). Effects of wheat pentosans on endogenous amino acid losses in chickens. Journal of the Science of Food and Agriculture 66, 399-404.

Annison, E. F., Hill, K. J. \& Kenworthy, R. (1968). Volatile fatty acids in the digestive tract of the fowl. British Journal of Nutrition 22, 207-216.

Annison, G. (1990). Polysaccharide composition of Australian wheats and the digestibility of their starches in broiler chicken diets. Australian Journal of Experimental Agriculture 30, 183-186.

Annison, G. (1992). Commercial enzyme supplementation of wheat-based diets raises ileal glycanase activities and improves apparent metabolisable energy, starch and pentosan digestibilities in broiler chickens. Animal Feed Science and Technology 38, 105-121.

Annison, G. (1993). The role of wheat non-starch polysaccharides in broiler nutrition. Australian Journal of Agricultural Research 44, 405-422.

Annison, G. \& Choct, M. (1991). Anti-nutritive activities of cereal non-starch polysaccharides in broiler diets and strategies minimizing their effects. World's Poultry Science Journal 47, 232-242.

Annison, G., Choct, M. \& Cheetham, N. W. (1992). Analysis of wheat arabinoxylans from a large-scale isolation. Carbohydrate Polymers 19, 151-159.

Argenzio, R. A. (1982). Volatile fatty acid production and absorption from the large intestine of the pig. Colloques de l'INRA 12, 207-216.

Autio, K. (1997). Functional aspects of cereal cell wall polysaccharides. In Carbohydrates in Food, pp. $227-264$ [A.C. Eliasson, editor]. Lund, Sweden: University of Lund.

Barrier-Guillot, B., Casado, P., Maupetit, P., Jondreville, C., Gatel, F. \& Larbier, M. (1996a). Wheat phosphorus availability. 1. In vitro study: factors affecting endogenous phytasic activity and phytic phosphorus content. Journal of the Science of Food and Agriculture 70, 62-68.

Barrier-Guillot, B., Casado, P., Maupetit, P., Jondreville, C., Gatel, F. \& Larbier, M. (1996b). Wheat phosphorus availability. 2. In vivo study in broilers and pigs; relationship with endogenous phytasic activity and phytic phosphorus content in wheat. Journal of the Science of Food and Agriculture 70, 69-74.

Bastawde, K. B. (1992). Xylan structure, microbial xylanases, and their mode of action. World Journal of Microbiology and Biotechnology 8, 353-368.

Bedford, M. R. (1995). The optimum dose of a xylanase-based enzyme offered to broilers fed a wheat based diet increases as the bird ages. Poultry Science 74, 18 (Abstr.).

Bedford, M. R. (1996a). Interaction between ingested feed and the digestive system in poultry. Journal of Applied Poultry Research 5, 86-95.

Bedford, M. R. (1996b). The effect of enzymes on digestion. Journal of Applied Poultry Research 5, 370-378.

Bedford, M. R. (1996c). Enzyme action-under the microscope. Feed Mix 4(5), 22-23.

Bedford, M. R. \& Autio, K. (1996). Microscopic examination of feed and digesta from wheat-fed broiler chickens and its relation to bird performance. Poultry Science 75 (Suppl. 1), 14.

Bedford, M. R. \& Classen, H. L. (1992a). The influence of dietary xylanase on intestinal viscosity and molecular weight distribution of carbohydrates in rye-fed broiler chicks. In Xylans and Xylanases, pp. 361-370 [J. Visser, editor]

Bedford, M. R. \& Classen, H. L. (1992b). Reduction of intestinal viscosity through manipulation of dietary rye and pentosanase concentration is effected through changes in the carbohydrate composition of the intestinal aqueous phase and results in improved growth rate and food conversion efficiency of broiler chicks. Joumal of Nutrition 122 , $560-569$.

Bedford, M. R., Classen, H. L. \& Campbell, G. L. (1991). The effect of pelleting, salt, and pentosanase on the viscosity of intestinal contents and the performance of broilers fed rye. Poultry Science 70,1571-1577.

Bedford, M. R. \& Inborr, J. (1993). Effect of increasing the dietary concentrations of two xylanases on the performance and intestinal viscosity of broiler chickens fed diets based on wheat and triticale. WPSA Proceedings of 9th European Symposium on Poultry Nutrition, Jelenia-Gora, Poland, pp. 485-489.

Bedford, M. R. \& Morgan, A. J. (1995). The use of enzymes in canola-based diets. In 2nd European Symposium on Feed Enzymes, Noordwijkerhout, pp. 125-131 [W. van Hartingsveldt, M. Hessing, J.P van der Lugt and W. A.C Somers, editors]. Zeist: TNO Nutrition and Food Research Institute.

Bedford, M. R. \& Morgan, A. J. (1996). The use of enzymes in poultry diets. World's Poultry Science Journal 52, 6168.

Bedford, M. R., Pack, M. \& Wyatt, C. L. (1997). Relevance of in feed analysis of enzyme activity for prediction of bird performance in wheat based diets. Poultry Science 76 (Suppl. 1), 39.

Bedford, M. R., Patience, J. F., Classen, H. L. \& Inborr, J. (1992). The effect of dietary enzyme supplementation of ryeand barley-based diets on digestion and subsequent performance in weanling pigs. Canadian Journal of Animal Science 72, 97-105. 
Beudecker, R. F. \& Pen, J. (1995). Development of plant seeds expressing phytase as a feed. In 2nd European Symposium on Feed Enzymes, Noordwijkerhout, pp. 225-231 [W. van Hartingsveldt, M. Hessing, J.P van der Lugt and W. A.C Somers, editors]. Zeist: TNO Nutrition and Food Research Institute.

Bhandari, S. D. (1980). Effect of phytate feeding with and without protein and vitamin D deficiencies on intestinal phytase activity in rat. Indian Journal of Biochemistry and Biophysics 17, 309-312.

Bhat, M. K. \& Bhat, S. (1997). Cellulose degrading enzymes and their potential industrial applications. Biotechnology Advances 15, 583-620.

Bulfield, G., Isaacson, J. H. \& Middleton, R. J. (1988). Biochemical correlates of selection for weight-for-age in chickens: twenty fold higher muscle ornithine decarboxylase levels in modern broilers. Theoretical and Applied Genetics 75, 432-437.

Caldwell, R. A. (1992). Effect of calcium and phytic acid on the activation of trypsinogen and the stability of trypsin. Journal of Agricultural and Food Chemistry 40, 43-46.

Campbell, G. L. \& Bedford, M. R. (1992). Enzyme applications for monogastric feeds: a review. Canadian Journal of Animal Science 72, 449-466.

Campbell, G. L., Classen, H. L. \& Goldsmith, K. A. (1983). Effect of fat retention on the rachitogenic effect of rye fed to broiler chicks. Poultry Science 62, 2218-2223.

Carre, B., Lessire, M., Nguyen, T. H. \& Larbier, M. (1992). Effects of enzymes on feed efficiency and digestibility of nutrients in broilers. In Proceedings, 19th World Poultry Congress, Amsterdam, pp. 411-415.

Cera, K. R., Mahan, D. C., Cross, R. F., Reinhart, G. A. \& Whitmoyer, R. E. (1988). Effect of age, weaning and postweaning diet on small intestinal growth and jejunal morphology in young swine. Journal of Animal Science 66, 574-584.

Chesson, A. \& Travis, A. J. (1997). Engineering improved forage degradation characteristics. In Recent Advances in Animal Nutrition, pp. 21-32. University of New England, Australia.

Choct, M. \& Annison, G. (1992). The inhibition of nutrient digestion by wheat pentosans. British Journal of Nutrition 67, $123-132$.

Choct, M., Hughes, R. J., Wang, J., Bedford, M. R., Morgan, A. J. \& Annison, G. (1996). Increased small intestinal fermentation is partly responsible for the anti-nutritive activity of non-starch polysaccharides in chickens. British Poultry Science 37, 609-621.

Classen, H. L., Campbell, G. L., Rossnagel, B. G., Bhatty, R. S. \& Reichert, R. D. (1985). Studies on the use of hulless barley in chick diets: deleterious effects and methods of alleviation. Canadian Journal of Animal Science 65, 725733.

Coelho, M. B. (1994). Vitamin stability in expanders. Feed Management 45(8), 10-15.

Cook, M. E. (1996) Immune regulation of nutrient metabolism. Proceedings, Summit II, Breed $x$ Nutrition, Athens, GA, pp. 6-10.

Cowan, W. D., Jorgensen, O. B., Rasmussen, P. B. \& Wagner, P. (1993). Role of single activity xylanase enzyme components in improving feed performance in wheat based poultry diets. Agro Food Industry Hi-Tech 4(4) 11-14.

Cowan, W. D., Korsbak, A., Hastrup, T. \& Rasmussen, P. B. (1996). Influence of added microbial enzymes on energy and protein availability of selected feed ingredients. Animal Feed Science and Technology 60, 311-319.

Dais, P. \& Perlin, A. S. (1982). High-field, ${ }^{13}$ C-N.M.R. spectroscopy of $\beta$-D-glucans, amylopectin, and glycogen. Carbohydrate Research 100, 103-116.

Dämmrich, K. (1987). Organ change and damage during stress--morphological diagnosis. In Biology of Stress in Farm Animals: an integrated approach (CEC Seminar, 1986), pp. 71-81 [P.R. Wiepkema \& P. W. M. van Adrichem, editors]. Dordrecht: Martinus Nijhoff.

Danicke, S., Simon, O., Jeroch, H. \& Bedford, M. R. (1995). Effect of fat source and xylanase supplementation on the performance and intestinal viscosity in rye fed birds. In 2nd European Symposium on Feed Enzymes, Noordwijkerhout, pp. 102-106 [W. van Hartingsveldt, M. Hessing, J.P van der Lugt and W. A. C. Somers, editors]. Zeist: TNO Nutrition and Food Research Institute.

Delcour, J. A., Vanhamel, S. \& Hoseney, R. C. (1991). Physicochemical and functional properties of rye nonstarch polysaccharides. II. Impact of a fraction containing water-soluble pentosans and proteins on gluten-starch loaf volumes. Cereal Chemistry 68, 72-76.

Dintzis, F. R., Lehrfeld, J., Nelsen, T. C. \& Finney, P. L. (1992). Phytate content of soft wheat bran as related to kernel size, cultivar, location, and milling and flour quality parameters. Cereal Chemistry 69, 577-581.

Dudkin, M. S., Sorochan, D. V. \& Kozlov, G. F. (1976). [The structure of the water-soluble arabinoxylan of wheat endosperm.] Khimiya Prirodnykh Soedinenii (1), 13-15.

Dungelhoef, M., Rodehutscord, M., Spiekers, H. \& Pfeffer, E. (1994). Effects of supplemental microbial phytase on availability of phosphorus contained in maize, wheat and triticale to pigs. Animal Feed Science and Technology 49, $1-10$.

Dusel, G., Kluge, H., Simon, O., Jeroch, H. \& Schulze, H. (1997). [Effect on intestinal viscosity and nutrient digestibility in piglets of NSP-hydrolysing enzymes in high cereal diets.] Proceedings, Society for Nutritional Physiology 6, 131-145.

Düsterhöft, E.-M., Linssen, V. A. J. M., Voragen, A. G. J. \& Beldman, G. (1997). Purification, characterization, and properties of two xylanases from Humicola insolens. Enzyme and Microbial Technology 20, 437-445. 
Edney, M. J., Campbell, G. L. \& Classen, H. L. (1989). The effect of $\beta$-glucanase supplementation on nutrient digestibility and growth in broilers given diets containing barley, oat groats or wheat. Animal Feed Science and Technology 25, 193-200.

Edney, M. J., Marchylo, B. A. \& MacGregor, A. W. (1991). Structure of total barley $\beta$-glucan. Journal of the Institute of Brewing 97, 39-44.

Edwards, C. A., Johnson, I. T. \& Read, N. W. (1988). Do viscous polysaccharides slow absorption by inhibiting diffusion or convection? European Journal of Clinical Nutrition 42, 307-312.

Edwards, H. M. (1993). Dietary 1,25-dihydroxycholecalciferol supplementation increases natural phytate phosphorus utilization in chickens. Journal of Nutrition 123, 567-577.

Ellis, P. R., Rayment, P. \& Wang, Q. (1996). A physico-chemical perspective of plant polysaccharides in relation to glucose absorption, insulin secretion and the entero-insular axis. Proceedings of the Nutrition Society 55, 881-898.

Entringer, R. P., Plumlee, M. P., Conrad, J. H., Cline, T. R. \& Wolfe, S. (1975). Influence of diet on passage rate and apparent digestibility by growing swine. Journal of Animal Science 40, 486-494.

Fengler, A. I. \& Marquardt, R. R. (1988a). Water soluble pentosans from rye. I. Isolation, partial purification, and characterization. Cereal Chemistry 65, 291-297.

Fengler, A. I. \& Marquardt, R. R. (1988b). Water-soluble pentosans from rye. II. Effects on rate of dialysis and on the retention of nutrients by the chick. Cereal Chemistry $65,298-302$.

Fisher, H. (1992). Low-calcium diets enhance phytate-phosphorus availability. Nutrition Reviews 50, $170-171$.

Friesen, K. G., Nelssen, J, L., Unruh, J. A., Goodband, R. D. \& Tokach, M. D. (1994). Effects of the interrelationship between genotype, sex, and dietary lysine on growth performance and carcass composition in finishing pigs fed to either 104 or 127 kilograms. Journal of Animal Science 72, 946-954.

Frolich, W. (1990). Chelating properties of dietary fiber and phytate, the role for mineral availability. In New Developments in Dietary Fiber, pp. 83-93 [I. Furda and C. J. Brine, editors]. New York: Plenum Press.

Fuller, M. F., Franklin, M. F., McWilliam, R. \& Pennie, K. (1995). The responses of growing pigs, of different sex and genotype, to dietary energy and protein. Animal Science 60, 291-298.

Gee, J. M., Lee-Finglas, W. \& Johnson, I. T. (1996). Fermentable carbohydrate modulates postprandial enteroglucagon and gastrin release in rats. British Journal of Nutrition 75, 757-766.

Girhammar, U. \& Nair, B. M. (1992a). Certain physical properties of water soluble non-starch polysaccharides from wheat, rye, triticale, barley and oats. Food Hydrocolloids 6, 329-343.

Girhammar, U. \& Nair, B. M. (1992b). Isolation, separation and characterization of water soluble non-starch polysaccharides from wheat and rye. Food Hydrocolloids 6, 285-299.

Grootwassink, J. W. D., Campbell, G. L. \& Classen, H. L. (1989). Fractionation of crude pentosanase (arabinoxylanase) for improvement of the nutritional value of rye diets for broiler chickens. Journal of the Science of Food and Agriculture 46, 289-300.

Guenter, W., Slominski, B. A., Simbaya, J., Campbell, L. D. \& Morgan, A. J. (1995). Potential for improved utilization of canola meal using exogenous enzymes. Proceedings, 9th International Rapeseed Congress, Cambridge, pp. 164 166.

Hancock, C. E., Bradford, G. D., Emmans, G. C. \& Gous, R. M. (1995). The evaluation of the growth parameters of six strains of commercial broiler chickens. British Poultry Science 36, 247-264.

Heredia, A., Jimenez, A. \& Guillen, R. (1995). Composition of plant cell walls. Zeitschrift für LebensmittelUntersuchung und -Forschung 200, 24-31.

Hessing, M., Mocking-Bode, H., Bleeker-Marcelis, H., Van Laarhoven, H., Rooke, J. A. \& Morgan, A. J. (1995). Quality of soybean meals and effect of microbial enzymes in degrading soya antinutritional compounds (ANCs) using immunochemical, microscopic techniques and in vivo studies. In 2nd European Symposium on Feed Enzymes Noordwijkerhout, pp. 176-177 [W. van Hartingsveldt, M. Hessing, J.P van der Lugt and W. A. C. Somers, editors]. Zeist: TNO Nutrition and Food Research Institute.

Hock, E., Halle, I., Matthes, S. \& Jeroch, H. (1997). Investigations on the composition of the ileal and caecal microflora of broiler chicks in consideration to dietary enzyme preparation and zinc bacitracin in wheat-based diets. Agribiological Research-Zeitschrift für Agrarbiologie, Agrikulturchemie, Ökologie 50, 85-95.

Holben, W. E. \& Harris, D. (1995). DNA based monitoring of total bacterial community structure in environmental samples. Molecular Ecology 4, 627-631.

Huisman, J. (1992). Aspects of anti-nutritional factors (ANFs) in relation to nutrition and pollution. Proceedings, 19th World Poultry Congress, Amsterdam, pp. 215-222.

Huisman, J. \& van der Poel, A. F. B. (1987). Effects of antinutritional factors (ANF) in pig nutrition. Proceedings, 38th Annual Meeting of EAAP, Portugal, pp. 117-128.

Huo, G. C., Fowler, V. R., Inborr, J. \& Bedford, M. R. (1993). The use of enzymes to denature antinutritive factors in soyabean. Proceedings, 2nd International Workshop on ANFs in Legume Seed, Wageningen, pp. $517-521$ [A.F.B. van der Poel, J. Huisman and H. S. Saini, editors]. Wageningen Pers.

Inborr, J., Bedford, M. R. \& Graham, H. (1994). Effect of enzyme supplementation on intestinal parameters in the pig. Proceedings, BSAP Winter Meeting, Scarborough, Paper 33.

Ito, K., Ogasawara, H., Sugimoto, T. \& Ishikawa, T. (1992). Purification and properties of acid stable xylanases from Aspergillus kawachii. Bioscience, Biotechology, and Biochemistry 56, 547-550.

Ito, S. (1997). Alkaline cellulases from alkaliphilic Bacillus-enzymatic properties, genetics, and application to detergents. Extremophiles 1(2), 61-66. 
Izydorczyk, M. S. \& Biliaderis, C. G. (1992a). Infiuence of structure on the physicochemical properties of wheat arabinoxylan. Carbohydrate Polymers 17, 237-247.

Izydorczyk, M. S. \& Biliaderis, C. G. (1992b). Effect of molecular size on physical properties of wheat arabinoxylan. Journal of Agricultural and Food Chemistry 40, 561-568.

Jackson, S. \& Diamond, J. (1996). Metabolic and digestive responses to artificial selection in chickens. Evolution 50, $1638-1650$.

Jansman, A. J. M., Schulze, H., Bosch, M. W. \& Leuvenink, H. (1996). Effect of xylanase supplementation to a wheat based diet on the portal fluxes of glucose and volatile fatty acids in pigs. Animal Science 74 (Suppl. 1), 19.

Jansman, A. J. M., Schulze, H., van Leeuwen, P. \& Verstegen, M. W. A. (1994). Effects of protease inhibitors and lectins from soya on the true digestibility and endogenous excretion of crude protein in piglets Proceedings, VIth Intermational Symposium on Digestive Physiology in Pigs (EAAP Publication 80), pp. 322-324 [W.-B. Souffrant and H. Hagemiester, editors].

Johansen, H. N., Wood, P. J. \& Bach Knudsen, K. E. (1993). Molecular weight changes in the (1->3)(1->4) $\beta$-Dglucan of oats incurred by the digestive processes in the upper gastrointestinal tract of pigs. Journal of Agricultural and Food Chemistry 41, 2347-2352.

Johnson I. T., Gee, J. M. \& Mahoney, R. R. (1984). Effect of dietary supplements of guar gum and cellulose on intestinal cell proliferation, enzyme levels and sugar transport in the rat. British Journal of Nutrition 52, $477-487$.

Jondreville, C., Brongniart, I., Gatel, F. \& Grosjean, F. (1995). [Effect of enzyme supplementation on the ileal digestibility of barley-based diets in growing pigs.] Journées de la Recherche Porcine en France 27, 217-222.

Jongbloed, A. W. \& Kemme, P. A. (1990). Effect of pelleting mixed feeds on phytase activity and the apparent absorbability of phosphorus and calcium in pigs. Animal Feed Science and Technology 28, 233-242.

Kanauchi, O., Deuchi, K., Imasato, Y., Shizukuishi, M. \& Kobayashi, E. (1995). Mechanism for the inhibition of fat digestion by chitosan and for the synergistic effect of ascorbate. Bioscience, Biotechnology, and Biochemistry 59, 786-790.

Kemme, P. A., Jongbloed, A. W., Mroz, Z. \& Beynen, A. C. (1997). The efficacy of Aspergillus niger phytase in rendering phytate phosphorus available for absorption in pigs is influenced by pig physiological status. Journal of Animal Science 75, 2129-2138.

Kirchgessner, M. \& Müller, H. L. (1991). Energy utilization via hindgut fermentation in pigs. In Digestive Physiology of the Hindgut (Advances in Animal Physiology and Animal Nutrition 22), pp. 41-49 [M. Kirchgessner, editor].

Kluepfel, D., Daigneault, N., Morosoli, R. \& Shareck, F. (1992). Purification and characterisation of a new xylanase (xylanase C) produced by Streptomyces lividans 66. Applied Microbiology and Biotechnology 36, 626-631.

Kormelink, F. J. M., Searle-Van Leeuwen, M. J. F., Wood, T.M. \& Voragen, A. G. J. (1993). Purification and characterisation of three endo- $(1,4)-\beta$-xylanases and one $\beta$-xylosidase from Aspergillus awamori. Journal of Biotechnology 27, 249-265.

Kornegay, E. T., Denbow, D. M., Yi, Z. \& Ravindran, V. (1996). Response of broilers to graded levels of microbial phytase added to maize-soyabean-meal-based diets containing three levels of non-phytate phosphorus. British Joumal of Nutrition 75, 839-852.

Kornegay, E. T., Denbow, D. M. \& Zhang, Z. (1997). Phytase supplementation of corn-soybean meal broiler diets from three to seven weeks of age. Poultry Science 76 (Suppl. 1), 6.

Krogdahl, A. \& Sell, J. L. (1989). Influence of age on lipase, amylase, and protease activities in pancreatic tissue and intestinal contents of young turkeys. Poultry Science 68, 1561-1568.

Lantzsch, H.-J., Hillenbrand, S., Scheuermann, S. E. \& Menke, K. H. (1992) Comparative study of phosphorus utilization from wheat, barley and com diets by young rats and pigs. Journal of Animal Physiology and Animal Nutrition 67, 123-132.

Larsen, F. M., Moughan, P. J. \& Wilson, M. N. (1993). Dietary fiber viscosity and endogenous protein excretion at the terminal ileum of growing rats. Journal of Nutrition 123, 1898-1904.

Leeson, S., Yersin, A. \& Volker, L. (1993). Nutritive value of the 1992 corn crop. Journal of Applied Poultry Research 2, 208-213.

Le Huerou-Luron, I., Lhoste, E., Wicker-Planquart, C., Dakka, N., Toullec, R., Corring, T., Guilloteau, P. \& Puigserver, A. (1993). Molecular aspects of enzyme synthesis in the exocrine pancreas with emphasis on development and nutritional regulation. Proceedings of the Nutrition Society 52, 301-313.

Lhoste, E. F., Fiszlewicz, M., Gueugneau, A. M., Wicker-Planquart, C., Puigserver, A. \& Corring, T. (1993). Effects of dietary proteins on some pancreatic mRNAs encoding digestive enzymes in the pig. Journal of Nutritional Biochemistry 4, 143-152.

Liebert, F., Kohler, R. \& Wecke, C. (1996). Studies concerning the proteolytic condition in the intestinal tract of chickens, as related to nitrogen and phosphorus utilization dependent on trypsin inhibitor activity and phytase addition in the diet. Journal of Animal Physiology and Animal Nutrition 75, 192-199.

Liener, I. E. (1994). Implications of antinutritional components in soybean foods. Critical Reviews in Food Science and Nutrition 34, 31-67.

Lindemann, M. D., Cornelius, S. G., El Kandelgy, S. M., Moser, R. L. \& Pettigrew, J. E. (1986). Effect of age, weaning and diet on digestive enzyme levels in the piglet. Journal of Animal Science 62, 1298-1307.

McConlogue, L., Gupta, M., Wu, L. \& Coffino, P. (1984). Molecular cloning and expression of the mouse ornithine decarboxylase gene. Proceedings of the National Academy of Sciences of the USA 81, 540-544. 
McKnight, W. F. (1997). A review of the use of Natuphos in broiler, layer and turkey diets. Proceedings, Minnesota Nutrition Conference, pp. 61-76.

McNab, J. M., Bernard, K., Knox, A. I., McNeill, L. \& Bedford, M. R. (1996). The effect of enzyme addition on digestibility of nitrogen and energy metabolism in young turkeys, broiler chickens and adult cockerels. Poultry Science 75 (Suppl. 1), 33.

Maenz, D. D., Engele-Schaan, C. M. \& Classen, H. L. (1997). Endogenous phytase activity in the small intestinal brush border membrane of broiler chicks and laying hens. Poultry Science 76, 71.

Mahagna, M. \& Nir, I. (1996). Comparative development of digestive organs, intestinal disaccharides and some blood metabolites in broiler and layer-type chicks after hatching. British Poultry Science 37, 359-371.

Makkink, C. A. \& Verstegen, M. W. A. (1990). Pancreatic secretion in pigs. Journal of Animal Physiology and Animal Nutrition 64, 190-208.

Manners, M. J. (1976). The development of digestive function in the pig. Proceedings of the Nutrition Society 35, 49 55.

Marquardt, R. R., Brenes, A., Zhang, Z. \& Boros, D. (1996) Use of enzymes to improve nutrient availability in poultry feedstuffs. Animal Feed Science and Technology 60, 321-330.

Mateos, G. G., Sell, J. L. \& Eastwood, J. A. (1982). Rate of food passage (transit time) as influenced by level of supplemental fat. Poultry Science 61, 94-100.

Matthaus, B. (1997). Antinutritive compounds in different oilseeds. Fett/Lipid 99, 170-174.

Matyka, S., Korol, W. \& Bogusz, G. (1990). The retention of phytin phosphorus from diets with fat supplements in broiler chicks. Animal Feed Science and Technology 31, 223-230.

Miles, R. D., Brown, R. D. J., Comer, C. W. \& Oelfke, E. (1996). Influence of an enzyme and an antibiotic on broiler performance. Journal of Applied Animal Research 9, 105-117.

Mitchell, M. A. \& Smith, M. W. (1991). The effects of genetic selection for increased growth rate on mucosal and muscle weights in the different regions of the small intestine of the domestic fowl (Gallus domesticus). Comparative Biochemistry and Physiology A 99, 251-258.

Morgan, A. J., Bedford, M. R., Tervila-Wilo, A., Autio, K., Hopeakoski-Nurminen, M., Poutanen, K. \& Parkkonen, T. (1995). How enzymes improve the nutritional value of wheat. Zootecnica International (April), $44-48$.

Mourot, J. \& Corring, T. (1979). Adaptation of the lipase-colipase system to dietary lipid content in pig pancreatic tissue. Annales de Biologie Animale, Biochimie, Biophysique 19(1A), 119-124.

Muramatsu, T., Hiramoto, K. \& Okumura, J. (1990). Strain differences in whole-body protein turnover in the chicken embryo. British Poultry Science 31, 91-99.

Näsi, M. (1990). Microbial phytase supplementation for improving availability of plant phosphorus in the diet of growing pigs. Journal of Agricultural Science in Finland 62, 435-443.

National Research Council (1994). Nutrient Requirements of Poultry, 9th rev. edn. Washington, DC: National Academy Press.

Nir, I., Nitsan, Z. \& Mahagna, M. (1993). Comparative growth and development of the digestive organs and of some enzymes in broiler and egg type chicks after hatching. British Poultry Science 34, 523-532.

Nissinen, V. (1994). Enzymes and processing: the effects and interaction of enzymes and hydrothermal pre-treatments and their contribution to feeding value. International Milling, Flour \& Feed (May), 17-18.

Nitsan, Z., Ben-Avraham, G., Zoref, Z. \& Nir, I. (1991). Growth and development of the digestive organs and some enzymes in broiler chicks after hatching. British Poultry Science 32, 515-523.

Noy, Y. \& Sklan, D. (1994). Digestion and absorption in the young chick. Poultry Science 73 366-373.

Ogawa, K. (1988).Purification and some properties of two endo-type cellulases from Trichoderma viride. Bulletin of the Faculty of Agriculture, Miyazaki University 35(1), 1-20.

Owsley, W. F., Orr, D. E. \& Tribble, L. F. (1986). Effect of age and diet on the development of the pancreas and the synthesis and secretion of pancreatic enzymes in the young pig. Journal of Animal Science 63, 497-504.

Parkkonen, T., Tervila-Wilo, A., Hopeakoski-Nurminen, M., Morgan, A. J., Poutanen, K. \& Autio, K. (1997). Changes in wheat microstructure following in vitro digestion. Acta Agriculturae Scandinavica 47B, 43-47.

Pasquier, B., Armand, M., Guillon, F., Castelain, C., Borel, P., Barry, J.-L., Pieroni, G. \& Lairon, D. (1996). Viscous soluble dietary fibres alter emulsification and lipolysis of triacylglycerols in duodenal medium in vitro. Journal of Nutritional Biochemistry 7, 293-302.

Peisker, M. (1992). High-temperature-short-time conditioning: physical and chemical changes during expansion. Feed International 13(2), 16-34.

Pen, J., Verwoerd, T. C., van Paridon, P. A., Beudeker, R. F., van den Elzen, P. J. M., Geerse, K., van der Klis, J. D., Versteegh, H. A. J., van Ooyen, A. J. J. \& Hoekema, A. (1993). Phytase-containing transgenic seeds as a novel feed additive for improved phosphorus utilization. Biotechnology 11, 811-814.

Pettersson, D. \& Åman, P. (1988). Effects of enzyme supplementation of diets based on wheat, rye or triticale on their productive value for broiler chickens. Animal Feed Science and Technology 20, 313-324.

Pettersson, D., Graham, H. \& Aman, P. (1990). Enzyme supplementation of broiler chicken diets based on cereals with endosperm cell walls rich in arabinoxylans or mixed-linked $\beta$-glucans. Animal Production 51, 201-207.

Pettersson, D., Graham, H. \& Aman, P. (1991). The nutritive value for broiler chickens of pelleting and enzyme supplementation of a diet containing barley, wheat and rye. Animal Feed Science and Technology 33, 1-14. 
Pickford, J. R. (1992). Effects of processing on the stability of heat labile nutrients in animal feeds. In Recent Advances in Animal Nutrition-1992, pp. 177-192 [P.C. Garnsworthy, W. Haresign, and D. J.A. Cole, editors]. London: Butterworth Heinemann Press.

Pinchasov, Y., Nir, I. \& Nitsan, Z. (1990). Metabolic and anatomical adaptations of heavy bodied chicks to intermittent feeding. 2. Pancreatic digestive enzymes. British Poultry Science 31, 769-777.

Pointillart, A. (1991). Enhancement of phosphorus utilization in growing pigs fed phytate-rich diets by using rye bran. Journal of Animal Science 69, 1109-1115.

Pointillart, A., Fontaine, N., Thomasset, M. \& Jay, M. E. (1985). Phosphorus utilization, intestinal phosphatases and hormonal control of calcium metabolism in pigs fed phytic phosphorus: soybean or rapeseed diets. Nutrition Reports Intemational 32, 155-167.

Poutanen, K. (1988). Characterization of xylanolytic enzymes for potential applications. Technical Research Centre of Finland Publication 47 (PhD Dissertation).

Poutanen, K., Tenkanen, M., Korte, H. \& Puls, J. (1991). Accesory enzymes involved in the hydrolysis of xylans. In Enzymes in Biomass Conversion (ACS Symposium Series 460), pp. 426-436 [G.F. Leatham and M. E. Himmel, editors]. Washington, DC: American Chemical Society.

Qian, H., Kornegay, E. T. \& Denbow, D. M. (1997). Utilization of phytate phosphorus and calcium as influenced by microbial phytase, cholecalciferol, and the calcium:total phosphorus ratio in broiler diets. Poultry Science 76, 37-46.

Rada, V. \& Marounek, M. (1996). Effect of monensin on the crop microflora of broiler chickens. Annales de Zootechnie 45, 283-288.

Ritz, C. W., Hulet, R. M., Self, B. B. \& Denbow, D. M. (1995). Growth and intestinal morphology of male turkeys as influenced by dietary supplementation of amylase and xylanase. Poultry Science 74, 1329-1334.

Saini, H. S. \& Henry, R. J. (1989). Fractionation and evaluation of triticale pentosans: comparison with wheat and rye. Cereal Chemistry 66, 11-14.

Sakamoto, K., Vucenik, I. \& Shamsuddin, A. M. (1993). [3H] phytic acid (inositol hexaphosphate) is absorbed and distributed to various tissues in rats. Joumal of Nutrition 123, 713-720.

Sauveur, B. (1989). [Phytic phosphorus and phytases in the nutrition of poultry.] INRA Productions Animales 2, 343-351.

Schoner, F.-J., Hoppe, P. P., Schwarz, G. \& Wiesche, H. (1993). [Comparison of microbial phytase and inorganic phosphate in male chickens: the influence on performance data, mineral retention and dietary calcium.] Journal of Animal Physiology and Animal Nutrition 69, 235-244.

Scott, T. A. \& Boldaji, F. (1997). Comparison of inert markers (chromic oxide or insoluble ash [Celite ${ }^{\mathrm{TM}}$ ]) for determining apparent metabolizable energy of wheat- or barley-based broiler diets with or without enzymes. Poultry Science 76, 594-598.

Sebastian, S., Touchburn, S. P., Chavez, E. R. \& Lague, P. C. (1996). Efficacy of supplemental microbial phytase at different dietary calcium levels on growth performance and mineral utilization of broiler chickens. Poultry Science 75, 1516-1523.

Segueilha, L., Lambrechts, C., Boze, H., Moulin, G. \& Galzy, P. (1992). Purification and properties of the phytase from Schwanniomyces castellii. Journal of Fermentation and Bioengineering 74, 7-11.

Sell, J. L., Koldovsky, O. \& Reid, B. L. (1989). Intestinal disaccharidases of young turkeys: temporal development and influence of diet composition. Poultry Science 68, 265-277.

Shimizu, M. (1992). Purification and characterization of phytase from Bacillus subtilis (natto) N-77. Bioscience, Biotechnology, and Biochemistry 56, 1266-1269.

Shoemaker, S., Watt, K., Tsitovsky, G. \& Cox, R. (1983). Characterization and properties of all cellulases purified from Trichoderma reesei strain L27. Biotechnology (Oct.), 687-690.

Simons, P. C. M., Versteegh, H. A. J., Jongbloed, A. W., Kemme, P. A., Slump, P., Bos, K. D., Wolters, M. G. E., Beudeker, R. F. \& Verschoor, G. J. (1990). Improvement of phosphorus availability by microbial phytase in broilers and pigs. British Joumal of Nutrition 64, 525-540.

Smits, C. H. M., Veldman, A., Verstegen, M. W. A. \& Beynen, A. C. (1997). Dietary carboxymethylcellulose with high instead of low viscosity reduces macronutrient digestion in broiler chickens. Journal of Nutrition 127, $483-487$.

Sooncharernying, S. \& Edwards, H. M. (1993). Phytate content of excreta and phytate retention in the gastrointestinal tract of young chickens. Poultry Science 72, 1906-1916.

Stern, S., Lundeheim, N. \& Andersson, K. (1995). Growth and carcass traits in pigs after selection for lean tissue growth rate on low and high protein diets. Animal Science 61, 341-346.

Sudendey, C. \& Kamphues, J. (1995). [Effect of enzyme addition (amylase, xylanase and $\beta$-glucanase) on digestive processes in the intestinal tract of force fed weaner piglets] Proceedings, Society for Nutritional Physiology 3, 145-171

Sunna, A. \& Antranikian, G. (1997). Xylanolytic enzymes from fungi and bacteria. Critical Reviews in Biotechnology 17, 39-67.

Tamminga, S., Schulze, H., van Bruchem, J. \& Huisman, J. (1995). The nutritional significance of endogenous N-losses along the gastro-intestinal tract of farm animals. Review. Archives of Animal Nutrition 48, 9-22.

Tenkanen, M., Schuseil, J., Puls, J. \& Poutanen, K. (1991). Production, purification and characterization of an esterase liberating phenolic acids from lignocellulosics. Journal of Biotechnology 18, 69-83. 
Tervila-Wilo, A., Parkkonen, T., Morgan, A. J., Hopeakoski-Nurminen, M., Poutanen, K., Heikkinen, P. \& Autio, K. (1996). In vitro digestion of wheat microstructure with xylanase and cellulase from Trichoderma reesei. Joumal of Cereal Science 24, 215-225.

Theander, O., Westerlund, E. \& Åman, P. (1993). Structure and components of dietary fiber. Cereal Foods World 38, 135-138, 140-141.

Torre, M., Rodriguez, A. R. \& Saura-Calixto, F. (1991). Effects of dietary fiber and phytic acid on mineral availability. Critical Reviews in Food Science and Nutrition 30, 1-23.

Uchiyama, Y. \& Watanabe, M. (1990). Development and comparative aspects of the pancreas. In Ultrastructure of the Extraparietal Glands of the Digestive Tract, pp. 99-113 [A. Riva and P. M. Motta, editors]. Kluwer Academic Publishers.

Ullah, A. H. J. \& Phillippy, B. Q. (1994). Substrate selectivity in Aspergillus ficuum phytase and acid phosphatases using myo-inositol phosphates. Journal of Agricultural and Food Chemistry 42, 423-425.

Uni, Z., Noy, Y. \& Sklan, D. (1995). Development of the small intestine in heavy and light strain chicks before and after hatching. British Poultry Science 36, 63-71.

van der Klis, J. D. \& van Voorst, A. (1993). The effect of carboxy methyl cellulose (a soluble polysaccharide) on the rate of marker excretion from the gastrointestinal tract of broilers. Poultry Science 72, 503-512.

van der Klis, J. D., van Voorst, A. \& van Cruyningen, C. (1993). Effect of a soluble polysaccharide (carboxy methyl cellulose) on the physico-chemical conditions in the gastrointestinal tract of broilers. British Poultry Science 34, 971983.

van der Klis, J. D., Versteegh, H. A. J., Simons, P. C. M. \& Kies A. K. (1997). The efficacy of phytase in corn-saybean meal-based diets for laying hens. Poultry Science 76, 1535-1542.

van der Klis, J. D., Verstegen, M. W. A. \& de Wit, W. (1990). Absorption of minerals and retention time of dry matter in the gastrointestinal tract of broilers. Poultry Science 69, 2185-2194.

Vinkx, C. J. A. \& Delcour, J. A. (1996). Rye (Secale cereale L.) arabinoxylans: a critical review. Journal of Cereal Science 24, 1-14.

Viveros, A., Brenes, A., Pizarro, M. \& Castano, M. (1994). Effect of enzyme supplementation of a diet based on barley, and autoclave treatment, on apparent digestibility, growth performance and gut morphology of broilers. Animal Feed Science and Technology 48, 237-251.

Vukic Vranjes, M. \& Wenk, C. (1996). Influence of Trichoderma viride enzyme complex on nutrient utilization and performance of laying hens in diets with and without antibiotic supplementation. Poultry Science 75, 551-555.

Wang, L., Newman, R. K., Newman, C. W. \& Hofer, P. J. (1992). Barley $\beta$-glucans alter intestinal viscosity and reduce plasma cholesterol concentrations in chicks. Joumal of Nutrition 122, 2292-2297.

White, W. B., Bird, H. R., Sunde, M. L., Marlett, J. A., Prentice, N. A. \& Burger, W. C. (1983). Viscosity of $\beta$-D-glucan as a factor in the enzymatic improvement of barley for chicks. Poultry Science 62, 853-862.

White, W. B., Bird, H. R., Sunde, M. L., Prentice, N. A., Burger, W. C. \& Marlett, J. A. (1981). The viscosity interaction of barley $\beta$-glucan with Trichoderma viride cellulase in the chick intestine. Poultry Science 60, 1043-1048

Widdowson, E. M. (1985). Development of the digestive system: comparative animal studies. American Journal of Clinical Nutrition 41, 384-390.

Wise, A. (1983). Dietary factors determining the biological activities of phytate. Nutrition Abstracts and Reviews $B$ 53, $791-806$

Wong, K. K. Y. \& Saddler, J. N. (1992). Trichoderma xylanases, their properties and application. Critical Reviews in Biotechnology 12, 413-435.

Wyatt, C. L., Moran, E. \& Bedford, M. R. (1997a). Utilizing feed enzymes to enhance the nutritional value of combased broiler diets. Poultry Science 76 (Suppl. 1), 39.

Wyatt, C. L., Soto-Salanova, M. \& Pack, M. (1997b). Applying enzymes to sorghum-based broíler diets. Proceedings, Australian Poultry Science Symposium 9, 116-118.

Yenigun, O., Kizilgun, F. \& Yilmazer, G. (1996). Inhibition effects of zinc and copper on volatile fatty acid production during anaerobic digestion. Environmental Technology 17, 1269-1274.

Yi, Z., Kornegay, E. T. \& Denbow, D. M. (1996a). Effect of microbial phytase on nitrogen and amino acid digestibility and nitrogen retention of turkey poults fed corn-soybean meal diets. Poultry Science 75, 979-990.

Yi, Z., Komegay, E. T., Ravindran, V., Lindemann, M. D. \& Wilson, J. H. (1996b). Effectiveness of Natuphos ${ }^{(\circledR)}$ phytase in improving the bioavailabilities of phosphorus and other nutrients in soybean meal-based semipurified diets for young pigs. Journal of Animal Science 74, 1601-1611.

Yoon, S. J., Choi, Y. J., Min, H. K., Cho, K. K., Kim, J. W., Lee, S. C. \& Jung, Y. H. (1996). Isolation and identification of phytase-producing bacterium, Enterobacter sp.4, and enzymatic properties of phytase enzyme. Enzyme and Microbial Technology 18, 449-454.

Źyła, K. (1992). Mould phytases and their application in the food industry. World Journal of Microbiology and Biotechnology 8, 467-472.

Źyła, K. (1993). The role of acid phosphatase activity during enzymic dephosphorylation of phytates by Aspergillus niger phytase. World Journal of Microbiology and Biotechnology 9, 117-119.

Źyła, K., Ledoux, D. R. \& Veum, T. L. (1995). Complete enzymic dephosphorylation of corn-soybean meal feed under simulated intesinal conditions of the turkey. Journal of Agricultural and Food Chemistry 43, $288-294$. 